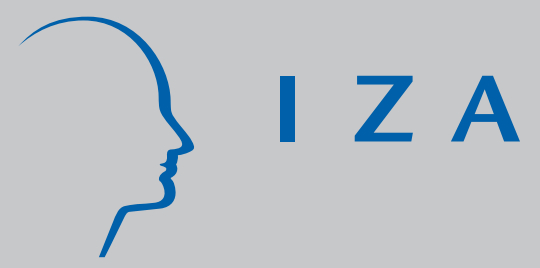

IZA DP No. 179

The Macroeconomics of Labor and Credit Market Imperfections

Etienne Wasmer

Philippe Weil

August 2000 


\title{
The Macroeconomics of Labor and Credit Market Imperfections
}

\author{
Etienne Wasmer \\ ECARES-ULB, CEPR and IZA, Bonn \\ Philippe Weil \\ ECARES-ULB, CEPR and NBER \\ Discussion Paper No. 179 \\ August 2000 \\ IZA \\ P.O. Box 7240 \\ D-53072 Bonn \\ Germany \\ Tel.: +49-228-3894-0 \\ Fax: +49-228-3894-210 \\ Email: iza@iza.org
}

This Discussion Paper is issued within the framework of IZA's research area Internationalization of Labor Markets and European Integration. Any opinions expressed here are those of the author(s) and not those of the institute. Research disseminated by IZA may include views on policy, but the institute itself takes no institutional policy positions.

The Institute for the Study of Labor (IZA) in Bonn is a local and virtual international research center and a place of communication between science, politics and business. IZA is an independent, nonprofit limited liability company (Gesellschaft mit beschränkter Haftung) supported by the Deutsche Post AG. The center is associated with the University of Bonn and offers a stimulating research environment through its research networks, research support, and visitors and doctoral programs. IZA engages in (i) original and internationally competitive research in all fields of labor economics, (ii) development of policy concepts, and (iii) dissemination of research results and concepts to the interested public. The current research program deals with (1) mobility and flexibility of labor markets, (2) internationalization of labor markets and European integration, (3) the welfare state and labor markets, (4) labor markets in transition, (5) the future of work, (6) project evaluation and (7) general labor economics.

IZA Discussion Papers often represent preliminary work and are circulated to encourage discussion. Citation of such a paper should account for its provisional character. 
IZA Discussion Paper No. 179

August 2000

\section{ABSTRACT \\ The Macroeconomics of Labor and Credit Market Imperfections}

Labor market frictions are not the only possible factor responsible for high unemployment. Credit market imperfections, driven by microeconomic frictions and impacted upon by macroeconomic factors such as monetary policy, could also be to blame. This paper shows that labor and credit market imperfections interact in a complementary way - which may explain why European and US unemployment differ so much when labor markets have become more similar at the margin in Europe and the US.

To develop this idea, we build a search model that treats credit and labor market imperfections in a symmetrical way. We introduce specificity in credit relationships, and assume that credit to potential entrepreneurs is rationed due to endogenous search frictions, in the spirit of Diamond (1990). These imperfections mirror the job search frictions that we introduce, à la MortensenPissarides (1994), in the labor market.

JEL Classification: J64, G24, E51

Keywords: Credit and search frictions, unemployment, monetary policy

Etienne Wasmer

ECARES

50 Avenue Franklin D. Roosevelt

CP 114

1050 Brussels

Belgium

Tel: +3226504212

Fax: +32 26504475

Email: ewasmer@ulb.ac.be 


\section{Introduction}

While macroeconomists and policy makers are often quick blame labor mar-

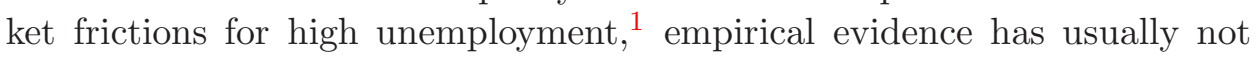
been very kind to the view that unemployment is purely, always and everywhere, a labor market phenomenon.?

Reinforcing this apparent puzzle, labor markets of countries like France, Spain or Italy have recently become more similar, at the margin at least, to that of the United States. There is now increased flexibility in European labor markets: temporary employment contracts have multiplied, and subsidies to low skill jobs are widespread. Yet, European economies remain sluggish while the US economy is booming, suggesting that labor market imperfections cannot explain, on their own, high unemployment.

Where are we to find, therefore, the missing pieces of the puzzle? Labor market frictions and wage rigidities are not the only deviation away from the Arrow-Debreu paradigm. Modern economies are plagued with a variety of informational imperfections in financial markets. Our claim is that moral hazard, adverse selection and search externalities in credit markets are relevant not only for finance but also for labor economics. ${ }_{\mathbf{L}}^{3.1}$

Indeed, there is a prevalent recognition that the major impediment to the creation of small firms is the difficulty to locate available credit. For instance, Blanchflower and Oswald (1998) report that raising capital is the principal problem of potential entrepreneurs: $20 \%$ of the respondents of the 1987 UK National Survey of the Self-Employed report that where to get finance was the biggest difficulty they encountered when becoming self-employed ${ }_{l_{1}}^{\overline{4} \text { In }}$ On top of that, $51 \%$ of the participants in the British Social Attitudes Survey who say they failed to become self-employed report, over the period 19831986, that lack of capital or money was the main reason of their failure. $\bar{p}$ Since 40 to $60 \%$ of jobs are held in small firms (less than 100 employees)

\footnotetext{
${ }^{1}$ See, notably, the OECD job studies.

${ }^{2}$ The recent OECD Employment Outlook (July 1999) shows, for instance, that the link between unemployment rates and labor market rigidities is at best tenuous across OECD countries.

${ }^{3}$ For an excellent survey on the importance for macroeconomics of credit market imperfections, see Easterly et al. (1999).

${ }^{4}$ Blanchflower and Oswald (1998), table 8.

${ }^{5}$ Blanchflower and Oswald (1998), table 6.

${ }^{6}$ These numbers are based on industry and market services. See OECD Job Study
} 
a theory of job creation and unemployment has to deal with difficulties in locating credit, and thus with credit market imperfections.

This is, of course, the foundation of the credit channel view of the transmission of monetary policy: new businesses, having poor access to credit markets, are the primary victims of monetary contractions.

Our objective in this paper is twofold. We want to think about the theory of unemployment in a environment in which the Modigliani-Miller theorem does not apply. And we want to build a specifically macroeconomic model of the interaction between credit and labor markets. To this end, we develop a model of firm creation in which new entrepreneurs are credit constrained and must raise funds before they enter the labor market to search for workers. Taking as our starting point that a competitive representation of the credit market would be as unrealistic as the assumption of perfect spot labor markets, we choose to model capital market imperfections and labor market imperfections in a perfectly symmetrical way.

To achieve this symmetry (and the simplicity it entails), we depart from usual models of credit imperfections. Economists traditionally focus on loan market imperfections that stem from moral hazard and/or adverse selection ${ }_{-!}^{\overline{1}}$, This type of imperfection is however not the driving force of our model. Instead, we take a leaf from the macro/labor literature, and use an alternative modeling strategy that has proved more tractable and fruitful in thinking about the macroeconomic aspects of labor markets: search theory. While recognizing that asymmetric information and moral hazard do in principle matter, we focus on credit and labor rationing that arise, in a world where agents are imperfectly aware of their economic opportunities, from the stochastic nature of the matching process between creditors and borrowers, workers and entrepreneurs. We thus follow, in the credit market, the lead taken by Pissarides (1990) in the labor market, and summarize at a highly abstract level the properties of the credit and labor matching processes by a pair of matching functions.

(1994).

${ }^{7}$ See, for instance, Gertler and Gilchrist (1994), Bernanke and Gertler (1989).

${ }^{8}$ See, for instance, Stiglitz and Weiss (1981) for microeconomic foundations, and Aghion et al. (1999) for macroeconomic applications.

${ }^{9}$ In labor markets, they lead to labor rationing and equilibrium unemployment. See, e.g., Shapiro-Stiglitz (1984).

${ }^{10}$ Matching functions reflect the fact that trading partners are not fully informed of each other's existence, because of horizontal heterogeneity in location, sectors of activity, type of skills, etc... This is different from more traditional vertical heterogeneity in which the 


\section{Main results}

Our model generates a decomposition of unemployment into two parts, one depending only on labor market imperfections (job search frictions and wage mark-up), and the other depending on credit market imperfections. This second term appears as an interaction term - the higher the level of the unemployment rate in the absence of credit frictions, the larger the increase in unemployment stemming from credit frictions.

Furthermore, we show that the equilibrium and comparative statics of our model are reminiscent of the IS/LM model. Credit market imperfections multiply the effect of profit shocks, and looser monetary policy lowers unemployment and slackens the credit market.

We then calibrate an economy in which the total pecuniary cost of credit frictions represents around $5.3 \%$ of annual GDP. We establish that credit frictions of that magnitude can raise unemployment to $10 \%$ compared to $6 \%$ in the absence of credit frictions.

The paper is organized as follows. Section 2 introduces the model. Section 3 derives the equilibrium. Section 4 presents the comparative statics of the model. Section 5 provides a simple formalization of the effects of monetary policy on credit and labor markets. Section 6 extends the model to endogenous wages, and discusses the role of debt as a strategic variable in wage negotiations. Section 7 attempts to assess empirically the interaction between credit and labor markets by exploring the links between venture capital investment and unemployment for 16 countries between 1986 and 1995. The conclusion summarizes and outlines directions for future research.

\section{The model}

\subsection{Entrepreneurs, workers and financiers}

There are three types of agents: entrepreneurs, workers and financiers. Entrepreneurs have ideas but they cannot work in production and have no capital of their own. Workers toil on the production line and transform the entrepreneurs' ideas into output; they have no entrepreneurial skills, and

no capital. Financiers have access to the financial resources required for

productivity of a job or of the worker, or the solvency of a creditor, are unknown. 
the concretization of the entrepreneurs' ideas, but they have no ideas and cannot work on the production line. entrepreneur, the worker and the financier in each of us. In our model, however, there is not. For simplicity, entrepreneurship, working and financing are assigned to mutually exclusive types of agents!

\subsubsection{Entrepreneurs and workers}

Producing output in a firm requires a team of one entrepreneur and one worker. There are labor market frictions, so that entrepreneurs and workers cannot meet easily. An entrepreneur must search at a flow cost $\gamma$ for the worker that will enable her to carry out her idea. We adopt the now standard device of Pissarides (1990), and subsume the process of matching workers to firms (which in principle involves heterogeneity, together with informational difficulties) into a simple constant returns to scale technology $h(\mathcal{U}, \mathcal{V})$ that "produces" a flow of matches between firms and workers with two "inputs:" job vacancies $\mathcal{V}$ posted by firms, and available (i.e., unemployed) workers $\mathcal{U}$.1 ${ }_{1}^{\prime \prime}$ ! Measuring labor market tightness (from the point of view of firms) by the index $\theta=\mathcal{V} / \mathcal{U}$, the instantaneous probability that an entrepreneur will find a worker is thus

$$
\frac{h(\mathcal{U}, \mathcal{V})}{\mathcal{V}}=h\left(\theta^{-1}, 1\right) \equiv q(\theta)
$$

Quite intuitively, the tighter the labor market, the less probable it is that an entrepreneur will meet an available worker $\left(q^{\prime}<0\right)$.

\subsubsection{Financiers and entrepreneurs}

Since an entrepreneur must expand resources to search for a worker before production even starts, a prerequisite to this search process is the financing of the entrepreneur's recruitment efforts. Traditional models of the labor market focus solely on labor market frictions, and conveniently assume away credit market frictions: entrepreneurs instantaneously finance the vacancies

\footnotetext{
${ }^{11}$ We will hereafter interchangeably refer to financiers or bankers.

${ }^{12}$ In the model, entrepreneurs are cash-constrained and need the financiers to obtain capital. More generally, firms could rely on financiers to provide other inputs (such as expertise, advice, or market knowledge) that they do not have.

${ }^{13}$ We impose, as usual, that marginal products in matching are positive but decreasing: $h_{1}>0, h_{2}>0, h_{11}<0, h_{22}<0$.
} 
they post either on their own or by borrowing on a perfect capital market.114 Credit markets, however, are plagued by frictions that do not differ much from those encountered in labor markets: there is considerable heterogeneity between prospective debtors, and informational difficulties hinder smooth contracting between borrowers and lenders. Instead of trying to specify in detail the nature of credit market frictions, we take a leaf from the labor economics literature and use the device of a matching function to formalize at an aggregative level the difficult relationship between financiers and entrepreneurs. ${ }_{-1}^{\top 5 !}$

The benefit of the matching function approach has been well demonstrated in the macro/labor literature: matching frictions generate specificity of economic relationships in a parsimonious way. This benefit overweighs, in our opinion, the (very minimal, as we shall see) danger that our results might differ in some subtle ways from microeconomic stories left untold by matching functions. Our paper therefore proposes to describe frictions and specificity symmetrically in credit markets and labor markets.116!

Formally, let $\mathcal{B}$ be the number of bankers looking for borrowers/entrepreneurs, and denote by $\mathcal{F}$ the number of entrepreneurs looking for financing. Each of these $\mathcal{F}$ entrepreneurs is searching at a flow private (non-pecuniary) cost $c$ for one the $\mathcal{B}$ available bankers. The flow of loan contracts successfully signed between financiers and entrepreneurs is given by the constant returns to scale credit market matching function $m(\mathcal{B}, \mathcal{F}) . I_{-}^{17}$. From the point of view of firms, credit market tightness can be measured by $\phi=\mathcal{F} / \mathcal{B}$. Equivalently, $1 / \phi$ is an index (for firms) of the liquidity of the credit market $18{ }_{1}^{1}$

\footnotetext{
${ }^{14}$ Which way they do it is irrelevant, as in Pissarides (1990).

${ }^{15}$ den Haan, Ramey and Watson (1999) and dell'Ariccia and Garibaldi (1999) also represent credit market frictions using a matching function. However, they do not consider interactions with labor market frictions.

${ }^{16}$ We share this objective with Caballero and Hammour (1998). Our paper differs from theirs in several dimensions. Our credit imperfections are stochastic (frictional) due to the matching approach of our model; theirs stem from the standard default problem. We build a financial contract which rules out heterogeneity across production units and allows to derive close form solution of the model, whereas Caballero and Hammour must take care of the distribution of debts and accordingly of the history of productive units (which substantially increases the complexity of their model). Finally, our focus, unlike theirs, is not on the efficiency aspect of cycles, but rather on labor markets and the transmission of credit and monetary policy.

${ }^{17}$ We impose $m_{1}>0, m_{2}>0, m_{11}<0, m_{22}<0$.

${ }^{18}$ Our concept of liquidity is the willingness of financiers to part from their resources to lend them to firms. It is similar to the notion of liquidity used in stock markets. There are of course other (more physical) meanings of liquidity studied in the literature - such as the
} 
The instantaneous probability that an entrepreneur/borrower will find a suitable financier is thus

$$
\frac{m(\mathcal{B}, \mathcal{F})}{\mathcal{F}}=m\left(\phi^{-1}, 1\right) \equiv p(\phi)
$$

while the success probability of a financier in his search for an entrepreneur is

$$
\frac{m(\mathcal{B}, \mathcal{F})}{\mathcal{B}}=m(1, \phi)=\phi p(\phi)
$$

Not surprisingly, the former probability is decreasing in credit market tightness, while the second is increasing.

\subsection{Four stages in the life of a firm}

The life of a firm can be decomposed into four successive stages of stochastic length: fund raising, recruitment, creation and destruction.

- Fund raising. In stage 0, prospective entrepreneurs are looking (at a flow search cost $c$ ) for a bank willing, in exchange for a future repayment, to finance the posting of a job vacancy, while financiers are searching for clients at a flow search cost $k$. The probability that an entrepreneur will find a financier (equivalently, the probability of transition to the recruitment stage) is $p(\phi)$.

- Recruitment. In stage 1, entrepreneurs have found a financier and are looking (at a flow search cost $\gamma$ borrowed from their financier) for the worker that will enable them to start operating their firm. The probability that an entrepreneur will meet a worker, and that the financing stage will end, is $q(\theta)$.

- Creation. In stage 2, the firm has found a worker and is generating exogenous flow profits $y$. It uses these profits to pay its workers an exogenous wage $\omega_{-}^{119 !}$ and by paying back to his financier a flow amount $\rho$ for as long as the productive unit operates. The repayment $\rho$ is negotiated between the financier and the entrepreneur.

volume of funds available for lending. For a leading analysis of liquidity as the availability of financial instruments available to transfer wealth across periods, see Holmström and Tirole (1998).

${ }^{19}$ We show in section ${ }_{6}^{1}$ that the results are not fundamentally different when the wage is negotiated between entrepreneurs and workers. 
- Destruction. In the final stage 3, the match between firm and worker is destroyed. We assume that destruction is exogenous - i.e., that the transition from stage 2 to 3 occurs with an exogenous probability $s$.

Throughout, we assume that their are no commitment problems for financiers, firms or workers.

\subsubsection{The value of a bank}

Call $B_{i},(i=0,1,2,3)$, the value of a bank in the fund raising, staffing, creation and destruction phases, and $r$ the (given) riskless rate. The Bellman equations describing the evolution of the value of the bank over these four stages are:

$$
\begin{aligned}
& r B_{0}=-k+\phi p(\phi)\left(B_{1}-B_{0}\right)+\dot{B}_{0}, \\
& r B_{1}=-\gamma+q(\theta)\left(B_{2}-B_{1}\right)+\dot{B}_{1}, \\
& r B_{2}=\rho+s\left(B_{3}-B_{2}\right)+\dot{B}_{2} .
\end{aligned}
$$

The financier suffers a cash outflow $-k$ in the fund-raising stage while it is looking for a client. It pays out a flow $-\gamma$ in the recruitment stage, while it finances the entrepreneur's posting of a job vacancy. Once the firm is created, the bank enjoys a cash inflow $\rho$ that corresponds to the repayment of its debt by the entrepreneur.

We assume that value of a bank destroyed after the financier has met the entrepreneur is zero: $B_{3}=0$.

\subsubsection{The value of an entrepreneur}

Let $F_{i}(\mathrm{i}=0,1,2,3)$ denote the value of an entrepreneurial unit in the fund raising, staffing, creation and destruction phases. It evolves as follows over the four stages of the life of the firm:

$$
\begin{aligned}
& r F_{0}=-c+p(\phi)\left(F_{1}-F_{0}\right)+\dot{F}_{0}, \\
& r F_{1}=q(\theta)\left(F_{2}-F_{1}\right)+\dot{F}_{1}, \\
& r F_{2}=y-\omega-\rho+s\left(F_{3}-F_{2}\right)+\dot{F}_{2},
\end{aligned}
$$


where $y$ denotes the exogenous flow profit of the firm once it starts operating. The value of a firm destroyed after the entrepreneur has met the financier is assumed to be zero:201 $F_{3}=0$.

\subsection{Bargaining between the financier and the entrepreneur}

The contract between a financier and an entrepreneur is written after they meet. The terms of the contract are i) that the bank will finance the recruitment cost of the entrepreneurs ( $\gamma$ per unit of time) for as long as it takes to find a worker, and that, in exchange, ii) the entrepreneur will repay the financier a constant amount $\rho$ per unit of time for as long as the firm operates. 2T' Note that we refer to this financial contract as a "loan" although it has equity-like aspects. The return to the financier depends on how quickly the firm finds a worker and on how long the firm will operate. In point of fact, the contract between financier and entrepreneur is very similar to a venture capital deal.

Financier and entrepreneur share the surplus of their relationship according to a generalized Nash bargaining rule

$$
\rho=\arg \max \left(B_{1}-B_{0}\right)^{\beta}\left(F_{1}-F_{0}\right)^{1-\beta},
$$

where $\beta \in(0,1)$ measures the bargaining power of financiers in the credit relationship.1. ${ }_{1}^{22 !}$ It follows that the stipulated loan repayment $\rho$ must satisfy

$$
\beta\left(F_{1}-F_{0}\right)=(1-\beta)\left(B_{1}-B_{0}\right) .
$$

\footnotetext{
${ }^{20}$ This assumption and the previous one $\left(B_{3}=0\right)$ are not essential. They amount to assuming that the project is destroyed by a shock which brings the present value of the project to less than zero, which means that each party wishes to withdraw from the project. All destructions are thus efficient in our model. The model can easily be extended to introduce inefficient destructions. See Caballero-Hammour (1998) on this point.

${ }^{21}$ An alternative to this particularly simple loan contract would be a loan schedule that would make repayment to the financier contingent on accumulated debt and on the time it took the entrepreneur to find a worker. This alternative contract would force us to introduce ex post heterogeneity between entrepreneurs - which we want to avoid.

${ }^{22}$ In a Rubinstein game of alternating offers and counter-offers, the parameter $\beta$ reflects the relative impatience of the negotiating parties.
} 


\section{Long-run equilibrium}

Assume it is costless to setup a bank or a firm. Free entry of financiers and entrepreneurs on the credit and labor market then ensures that, in equilibrium, there are no unexploited profit opportunities:

$$
B_{0}=0 \quad \text { and } \quad F_{0}=0 .
$$

\subsection{Equilibrium credit market tightness}

From the free entry conditions $\left(\overline{3} . \bar{l}_{i}\right)$ (which imply that $\dot{B}_{0}=\dot{F}_{0}=0$ ) and from the fund-raising stage value functions $\left(\begin{array}{l}2 \\ 2\end{array} \overline{1}\right)$ and $\left(\begin{array}{l}2 \\ 2\end{array}\right.$ follows by reading period 0 Bellman equations backwards that

$$
B_{1}=\frac{k}{\phi p(\phi)}
$$

while

$$
F_{1}=\frac{c}{p(\phi)}
$$

In a less liquid credit market (higher $\phi$ ), the equilibrium value of a (matched) financier is lower, while the value of a (matched) firm is higher - as financiers have to search less and firms more when there are more firms relative to banks.

Since the surplus of the banking relationship is shared between financier and entrepreneur according to $\left(\overline{2}-\overrightarrow{7}_{1}\right)$, we immediately conclude that

Proposition 1 In equilibrium, the tightness of the credit market is

$$
\phi^{*}=\frac{1-\beta}{\beta} \frac{k}{c}
$$

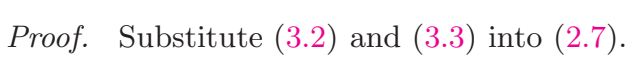

The lower the flow cost for financiers of looking for a suitable lender, and the higher the flow cost for entrepreneurs of searching for a banker, the lower $\phi$ (i.e., the higher the number of available financiers relative to the number of 
entrepreneurs raising funds). Moreover, the less profitable the sharing of the surplus of the credit relationship is to the bank, the tighter the credit market (higher $\phi$ ). Remarkably, $\phi$ and hence the value of the financier and of the entrepreneur are constant in equilibrium and do not depend on $\theta$-which

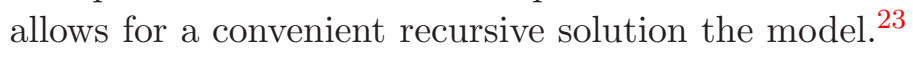

\subsection{Equilibrium financial contract}

The equilibrium repayment of the entrepreneur to her financier can now be calculated. Banker and entrepreneur must share the expected present discounted value of the profits, net of wages, that the firm will generate once it starts operating. The stronger the bargaining power of the bank relative to the entrepreneur, the larger the share of the profits that it will claim. Indeed, we can establish:

Proposition 2 In equilibrium, the repayment flow from entrepreneur to financier is

$$
\rho=\beta(y-\omega)+(1-\beta)(r+s) \gamma / q(\theta)
$$

Proof. The proof is by forward substitution of the Bellman equations. From equations

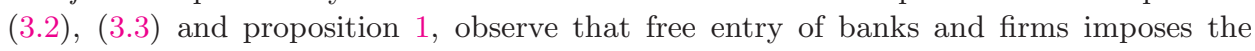
constancy of the value of the bank and of the firm in the fund-raising stage. Therefore, $\dot{B}_{1}=\dot{F}_{1}=0$ in equilibrium. But then the Bellman equations in the recruitment stage, $(2.25)$ and (2.5), imply that, in equilibrium,

$$
B_{1}=\frac{-\gamma+q(\theta) B_{2}}{r+q(\theta)}
$$

and

$$
F_{1}=\frac{q(\theta) F_{2}}{r+q(\theta)} .
$$

Similarly, the "exit" equations $B_{3}=0$ and $F_{3}=0$ imply that $\dot{B}_{2}=\dot{F}_{2}=0$, so that we

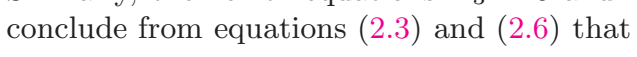

$$
B_{2}=\frac{\rho}{r+s}
$$

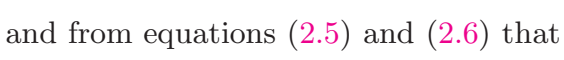

$$
F_{2}=\frac{y-\omega-\rho}{r+s} .
$$

\footnotetext{
${ }^{23}$ This recursivity of the solution is not general. It is due to the particular combination of assumptions made so far: constant returns to scale assumption on the matching function $h$, generalized Nash bargaining, and same discount factors for all agents. In section 5 , where we relax the latter assumption to discuss the effect of monetary policy, the equilibrium values of $\phi$ and $\theta$ must be calculated simultaneously, rather then recursively.
} 
By forward substitution of ( (equilibrium) Nash bargaining condition $\beta F_{1}=(1-\beta) B_{1}$ that the value of $\rho$ must be the one given in the proposition.

To interpret this proposition, it is convenient to rewrite $\rho$ as

$$
\rho \frac{q}{(r+q)(r+s)}=\beta(y-\omega) \frac{q}{(r+q)(r+s)}+(1-\beta) \frac{\gamma}{r+q},
$$

where we have dropped the argument of $q$ for brevity.

The term on the left is the expected present discounted value, evaluated at the instant financier and entrepreneur meet, of the flow repayment the entrepreneur between the random dates the firm will start and stop producing. The first term on the right is the expected present discounted value of profits, net of wages, generated by the firm while in operation-computed, again, from the perspective of the instant financier and entrepreneur meet. Finally, the second term on the right-hand side of (pected present discounted value of the flow of funds loaned by the financier to the entrepreneur from the time they meet until the random time the firm finds a worker and starts producing.

The equilibrium Nash-bargaining loan contract described by proposition and equation (3. of repayments from the entrepreneur to the financier is a weighted average of the expected present discounted value of the firm's profits net of wages, and of the expected present discounted value of the loan made by the financier to the entrepreneur, with the weights given by the respective bargaining power of financier and entrepreneur. The larger the bargaining power of the financier in the credit contract negotiation (i.e., the larger $\beta$ ), the larger the share of the expected present discounted value of profits net of wages that he can extract from the entrepreneur. Conversely, the stronger the bargaining

\footnotetext{
${ }^{24}$ Formally, let $T_{1}, T_{2}$ and $T_{3}$ denote the random times when, respectively, financier and entrepreneur meet (i.e., the beginning of the recruitment period), entrepreneur and worker meet (the beginning of the creation stage), and entrepreneur and worker are separated (destruction). Then, from the properties of the exponential distribution, we see that the expected present discounted value at $T_{1}$ of a flow of $\$ 1$ between $T_{1}$ and $T_{2}$ is $\mathrm{E}\left\{\int_{T_{1}}^{T_{2}} \mathrm{e}^{-r\left(s-T_{1}\right)} d s \mid T_{1}\right\}=1 /(r+q)$, while the expected present discounted value at $T_{1}$ of a flow of $\$ 1$ between $T_{2}$ and $T_{3}$ is $\mathrm{E}\left\{\int_{T_{2}}^{T_{3}} \mathrm{e}^{-r\left(s-T_{1}\right)} d s \mid T_{1}\right\}=q /[(r+s)(r+q)]$. The former expected present value rises, and the later declines, the smaller $\theta$, as date $T_{2}$ will on average arrive faster when $\theta$ is small (as $q^{\prime}<0$ ).
} 
power of the entrepreneur, (i.e., $\beta$ close to zero), the closer the value of the firm's repayment to the expected present discounted value of what it has borrowed.

Increased tightness $\theta$ of the labor market raises the repayment $\rho$. The tighter the labor market, the longer it will take for the firm to find a worker and to start producing ( since $q^{\prime}<0$ ), and the longer the bank will have to finance the entrepreneur. Consequently, the equilibrium loan contract specifies that the entrepreneur should on average repay more when labor markets are tight.

Should we conclude from proposition 2.21 that our model predicts, counterintuitively, that the equilibrium loan contract depends on the state of the labor market $\theta$ but not on the tightness of the credit market? No, because we have not yet computed the equilibrium $\theta$.

\subsection{Equilibrium labor market tightness}

To complete the description of equilibrium, it suffices to notice that in equilibrium the expected search costs that financiers and entrepreneurs incur by entering the credit market must equal the expected benefits that they derive from eventually striking out a financial relationship. Therefore:

Proposition 3 Equilibrium credit market tightness $\phi$ and labor market tightness $\theta$ are the solution to the pair of equations

$$
\begin{aligned}
\frac{k}{\phi p(\phi)} & =\beta \frac{q(\theta)}{r+q(\theta)}\left\{\frac{y-\omega}{r+s}-\frac{\gamma}{q(\theta)}\right\}, \\
\frac{c}{p(\phi)} & =(1-\beta) \frac{q(\theta)}{r+q(\theta)}\left\{\frac{y-\omega}{r+s}-\frac{\gamma}{q(\theta)}\right\} .
\end{aligned}
$$

Proof. Equations $(\underline{3} . \overline{2})$ and $\left(\underline{3} \cdot-3^{n}\right)$ provide us with backward-looking expressions for $B_{1}$ and $F_{1}$ that depend on solely $\phi$ : it is these expressions that we read on the right-hand

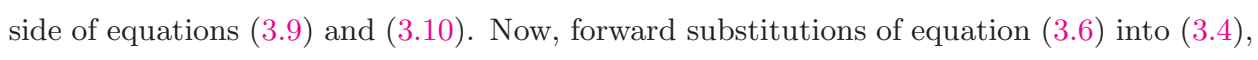
and of equation $\left(\hat{z}_{1}\right)$ into $\left(\hat{z}_{1}\right)$ provide us with two alternative formulas $B_{1}$ and $F_{1}$ that depend on the endogenous parameters $\rho$ and $\theta$. Substituting out $\rho$ out of these formulas using proposition 2 we get alternative expressions for $B_{1}$ and $F_{1}$ that depend only on

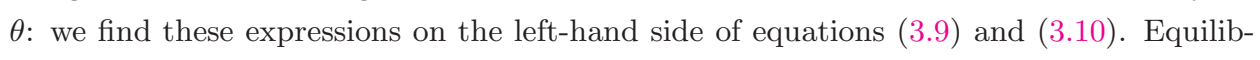
rium requires that the backward and forward expressions for $B_{1}$ and $F_{1}$ coincide- whence proposition 
To understand what equation $\left(\begin{array}{l}0 \\ \text { and }\end{array}\right)$ means, place yourself at the time a financier decides to enter the market. Before the financier meets a entrepreneur, he will on average spend

$$
\frac{k}{r+\phi p(\phi)}
$$

a cost which, quite naturally, depends exclusively on the state of the credit market. ${ }_{1}^{251}$ - When he meets the entrepreneur, he will get a fraction $\beta$ of the total surplus of the relationship (the term in curly bracket on the right-hand side of $(\overline{3} .98)$. The present discounted value, measured at entry time, of this future benefit, is:

$$
\frac{\phi p(\phi)}{r+\phi p(\phi)}\left\{\frac{q(\theta)[y-\omega]}{[r+q(\theta)](r+s)}-\frac{\gamma}{r+q(\theta)}\right\} \beta
$$

Equation (1, of entering the market equals the expected benefit he will derive from interacting with an entrepreneur. If the expected cost of entry is higher because the credit market is looser (i.e., there are many financiers chasing few entrepreneurs), it must be compensated in equilibrium, for entry to occur, by a larger benefit. This larger benefit stems from a looser labor market (i.e., many vacancies relative to unemployment) which shortens the expected duration of the recruiting stage. Equation ( sloping iso-value $\left(B_{0}=0\right)$ locus in $(\theta, \phi)$ space.

A similar interpretation applies, mutatis mutandis, to equation (30i). It defines a downward sloping iso-value $\left(F_{0}=0\right)$ locus in $(\theta, \phi)$ space, depicting the trade-off for the entering firm between a tighter credit market (which raises the expected cost of searching for a bank) and a looser labor market (which lowers the expected cost of finding a worker).

Equilibrium is depicted graphically in Figure (2), the BB and FF loci intersect at $\phi^{*}=[(1-\bar{\beta}) / \beta] /[k / c]$. Moreover, figure shows that existence and uniqueness of equilibrium are easy to guarantee.

\footnotetext{
${ }^{25}$ Let $T_{0}$ the date at which the banker enters the market and starts searching for an entrepreneur. Then $\mathrm{E}\left\{\int_{T_{0}}^{T_{1}} \mathrm{e}^{-r\left(s-T_{0}\right)} d s \mid T_{0}\right\}=1 /[r+\phi p(\phi)]$.

26 The expected value at time $T_{0}$ of $\$ 1$ at time $T_{1}$ is $\mathrm{E}\left\{\mathrm{e}^{-r\left(s-T_{0}\right)} \mid T_{0}\right\}=[\phi p(\phi)] /[r+$ $\phi p(\phi)]$.

${ }^{27}$ Let $\phi_{B}$ be such that $k /\left[\phi_{B} p\left(\phi_{B}\right)\right]=\beta(y-\omega) /(r+s)$, and $\phi_{F}$ be such that $c /\left[p\left(\phi_{F}\right)\right]=$ $\beta(y-\omega) /(r+s)$. Figure $\eta_{i}^{\prime}$ shows that a necessary and sufficient condition for existence and
} 


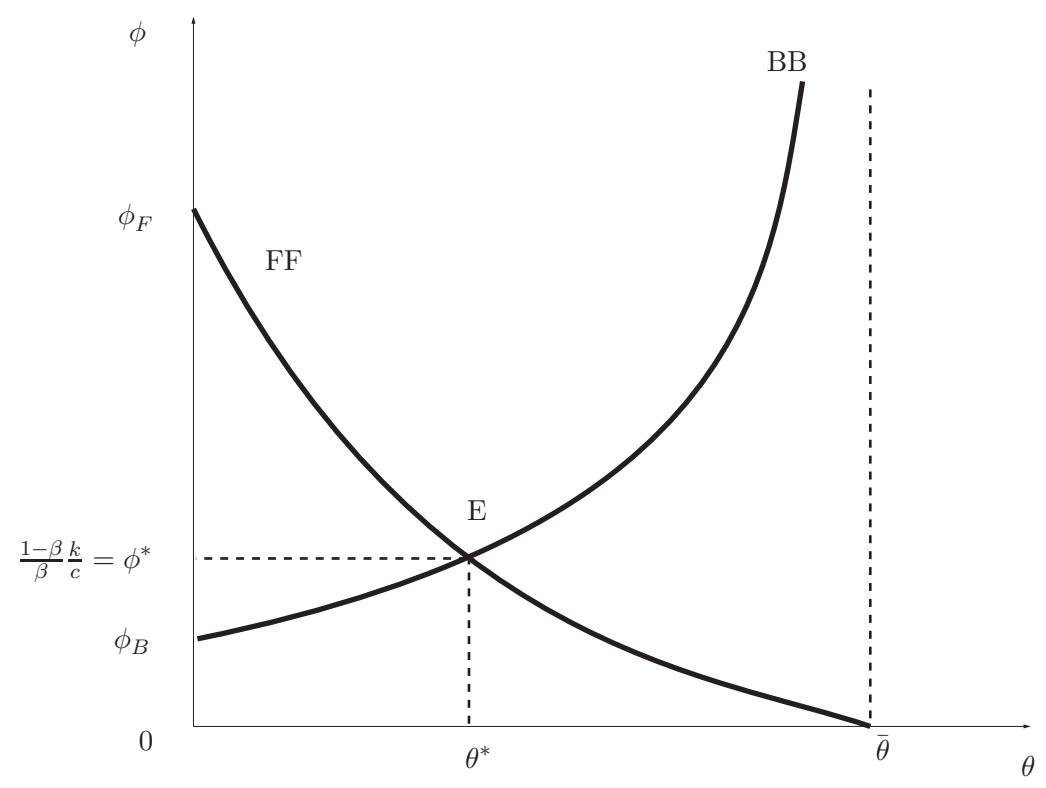

Figure 1: Equilibrium with exogenous wage

Note that figure $\prod_{1}^{\overline{1}}$ offers a picture of our economy that is reminiscent of the IS/LM model - although our FF/BB model rests on different theoretical foundations. On the horizontal axis, higher values of $\theta$ are associated with larger gross output, since gross output rises with labor market tightness.$_{-1}^{1281}$ On the vertical axis, we have a measure of the tightness of credit markets, $\phi$, that replaces the interest rate of the IS/LM model. The FF and BB curves "stand in" for the IS and LM curves. Sections of the comparative statics of our FF/BB framework with that of the IS/LM model.

Finally, observe that our model nests the Pissarides equilibrium. The equilibrium without credit market frictions obtains when either $k=0$, or $c=0$ or $p(\phi)=+\infty$ for all $\phi$. Equilibrium tension in the labor market in the

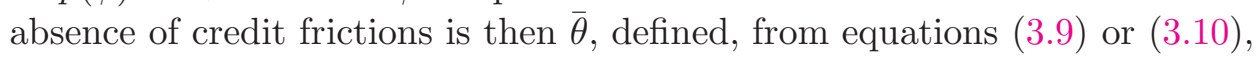

uniqueness of equilibrium is $\phi_{B}<\phi_{F}$. We assume that this restriction on the parameters of the model is satisfied.

${ }^{28}$ See section 
by

$$
\frac{y-\omega}{r+s}=\frac{\gamma}{q(\bar{\theta})} .
$$

This means that in the absence of credit frictions the value of newly created firm (matched with a banker but not with a worker) is zero-which is indeed the Pissarides free-entry condition for firms when there are no credit search frictions.

How does $\theta$ compare with $\bar{\theta}$ ? The answer is provided by inspection of figure 1', or more formally by

Proposition 4 Credit market imperfections lower equilibrium labor market tightness: $\theta^{*}<\bar{\theta}$.

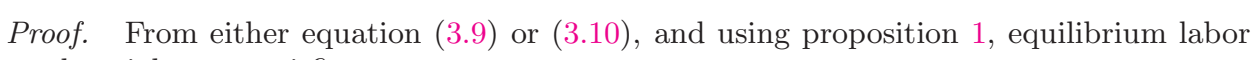
market tightness satisfies

$$
\gamma / q\left(\theta^{*}\right)=\gamma / q(\bar{\theta})-\frac{c}{1-\beta}\left[p\left(\frac{1-\beta}{\beta} \frac{k}{c}\right)\right]^{-1}<\gamma / q(\bar{\theta}) .
$$

Since $q^{\prime}()<$.0 , it follows that $\theta^{*}<\bar{\theta}$.

The second term on the righthand side of the equality sign in equation (3.1i $)$ summarizes the effects of credit market frictions on equilibrium labor market tightness. For given labor market frictions and profit conditions (i.e., given $q(),. \gamma$ and $\bar{\theta}$ ), equilibrium $\theta^{*}$ is higher the larger the credit search costs $k$ or $c$, and the stronger credit market frictions.2'!

All our results about equilibrium labor market tightness of course translate directly into statements about equilibrium unemployment and gross output, since unemployment rises and gross output declines when $\theta$ rises. In particular, credit frictions unambiguously raise equilibrium unemployment relative to the Pissarides model. Accordingly, given labor market frictions and profit conditions, our model predicts the existence of a positive relationship between equilibrium unemployment and credit market frictions. This prediction will be the base of our empirical investigation of section $\underline{\mathbf{T}_{1}}$.

\subsection{A Beveridge curve representation}

To characterize the effects of credit market imperfections on job vacancies and unemployment and to complete the solution of our model, it suffices

\footnotetext{
${ }^{29}$ As captured by upward shifts in the function $p($.$) .$
} 


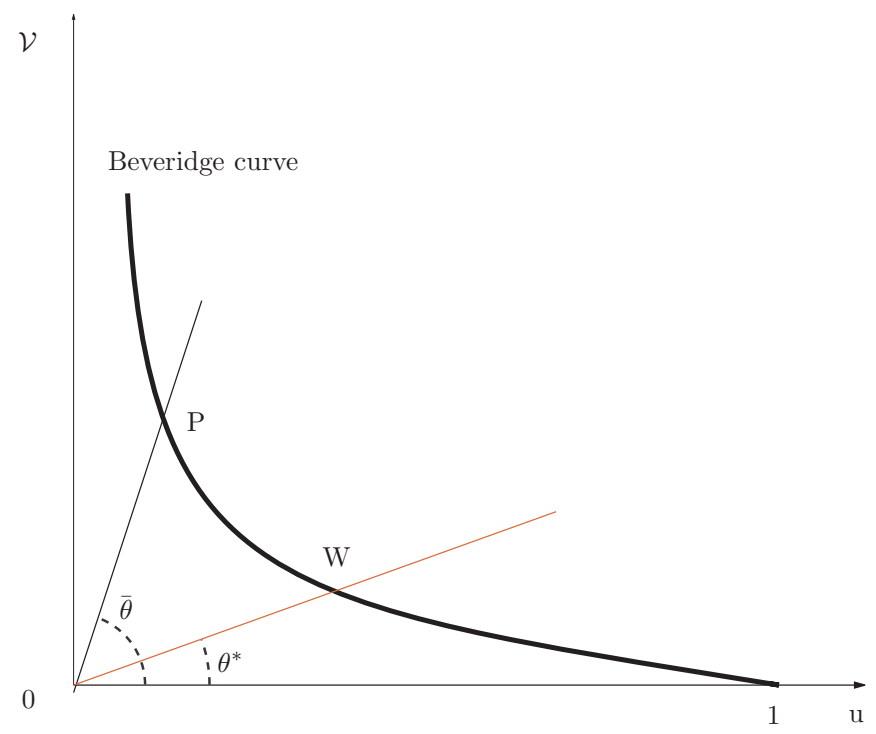

Figure 2: Beveridge curve (P: Pissarides equilibrium; W: equilibrium with credit market imperfections)

to represent equilibrium as the intersection of the Beveridge curve (defined below) and of the ray representing equilibrium labor market tightness in the $(\mathcal{U}, \mathcal{V})$ plane.

Let $u$ denote the unemployment rate. Normalize the mass of workers to 1 , so that $u=\mathcal{U}$. In steady state, flows in and out of the unemployment pool must equilibrate, so that

$$
s(1-u)=\theta q(\theta) u .
$$

Since $\theta=\mathcal{V} / u$, the equation of the Beveridge curve is $u=s /[s+(\mathcal{V} / u) q(\mathcal{V} / u)]$, which can be shown, given our assumptions, to be decreasing and convex.

Now, we know that in equilibrium we must also have

$$
\theta^{*}=\mathcal{V} / u
$$

Equilibrium job vacancies and unemployment are therefore determined graphically in figure $\stackrel{\overline{1}}{\mathrm{r}}$ 


\section{Comparative statics}

We now examine how equilibrium credit and labor market tightness react, in our economy, to changes in fundamental parameters. We provide both qualitative (graphical) answers, and quantitative measures (based on loglinearization) of the effects at work.

\subsection{Qualitative comparative statics}

Let us look in turn at the effect on equilibrium of higher search costs for banks, of lower search costs for firms, and of improved firms' net profits.

\subsubsection{Higher search costs for banks}

What happens if the banks' search cost $k$ rises? Inspection of equations $\left(\overline{3} .9_{i}^{\prime}\right)$ and $\left(\bar{B}^{2} . \overline{1}\right)$ reveals that the BB curve shifts up and to the left (for any given level $\theta$, a higher $k$ induces exit by financiers and raises $\phi$ ), while the FF curves stays unchanged (firms entry decisions are not directly affected by $k$ ). As a result, the credit market tightens and the labor market slackens, as depicted in figure $\overline{3}$.

The basic mechanism is simple: higher search costs make some financiers exit the credit market. The resulting tightening of the credit market induces some firms to exit, which lowers $\theta$ and mitigates the tightening of credit market - through a move along the FF curve.

If we think, admittedly with some poetic license, of higher search costs for banks as being induced by tighter monetary policy or more restrictive credit conditions, 150 , these comparative statics are quite similar qualitatively to that associated with contractionary monetary policy in the IS/LM model: tighter monetary policy lowers output and tightens the credit market.

\subsubsection{Lower credit search costs for entrepreneurs}

What happens if the firm's fundraising cost goes down? Lower credit search $\operatorname{cost} c$ for firms induces entry of new entrepreneurs at any given level of

\footnotetext{
${ }^{30}$ We examine a more prosaic version of monetary policy in section
} 


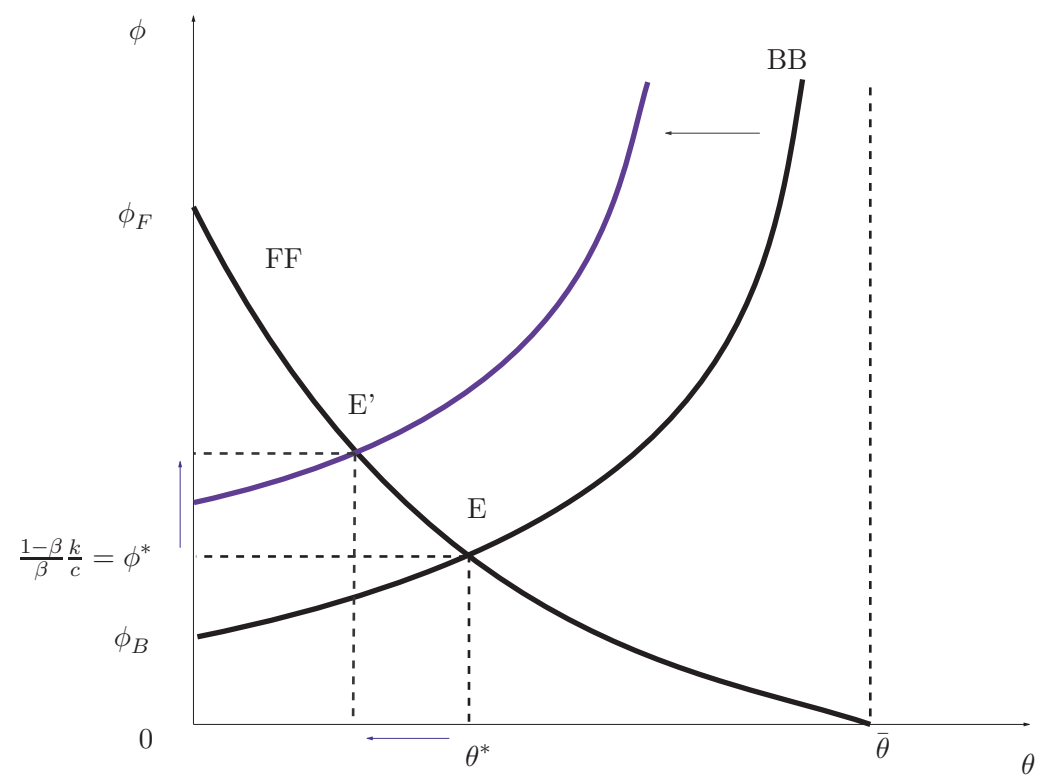

Figure 3: Increase in the bank's search cost $k$

credit market tightness: the FF curves shifts out and to the right. The banks' entry decisions are not directly affected by $c$, so that BB does not move.

In equilibrium, entry of new firms tightens both the credit and labor markets (a move along the BB curve), but the tightening of the credit market is mitigated by the entry of new financiers trying to take advantage of the increase in the number of entrepreneurs looking for credit. Equilibrium is depicted in figure 商.

Note that the parameter $c$ that we have been shifting captures among other things the administrative costs of financing new firms, which are influenced in particular by red tape and socio-cultural frictions.! 37 !

\footnotetext{
${ }^{31}$ These costs can be flow costs as in our model. Or they can be fixed costs, in which case can view $c$ as their flow equivalent.
} 


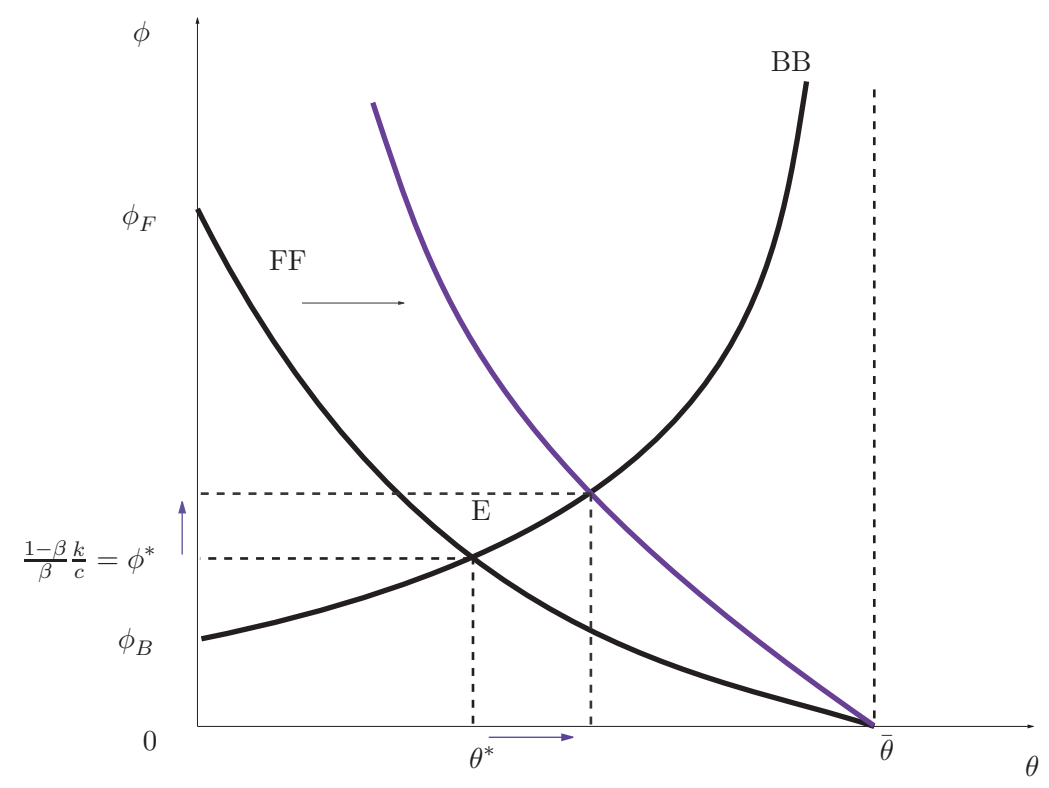

Figure 4: Decrease in the firm's search cost $c$

\subsubsection{Improvement in firms' net profits}

Imagine firms net profits $y-\omega$ increase. This increased profitability directly affects the entry decisions of both firms and financiers by increasing the size of the surplus that entering banks and firms will eventually split. As a result, for any given credit tightness $\phi$, more firms are willing to search when $y-\omega$ is higher, so that the FF curve shifts out and to the right. At the same time, for any given labor market tightness, more financiers are willing to search when $y-\omega$ is high, so that the BB curve shift down and to the right. Figure 空depicts the equilibrium: credit market tightness is ultimately unchangedist, but the labor market tightens and unemployment declines.

Figure fected directly firms' entry decisions (i.e., if the BB curve did not shift to the right at the same time FF does), an increase in net profits would tighten the labor market but to a lesser degree, and the credit market would tighten. The shift in the BB curve that is concomitant with the shift in the FF curve amplifies the tightening of the labor market, and eliminates (or more gener-

\footnotetext{
${ }^{32}$ This is a result of proposition
} 


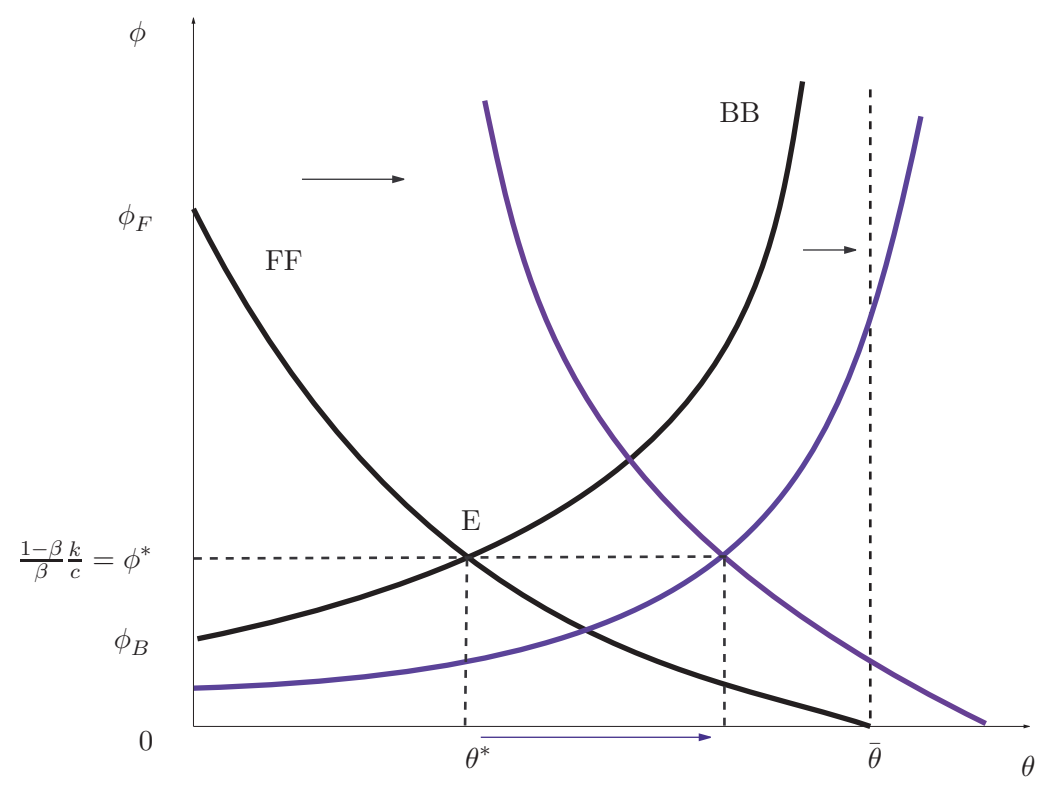

Figure 5: Increase in net profits $y-\omega$

ally attenuates) the tightening of the credit market. In the next subsection, we will see how this profit multiplier manifests itself formally.

\subsection{Quantitative implications}

The qualitative comparative statics results we have just presented do not tell us much about the quantitative relevance of the labor and credit market frictions. To get a feeling for the size of the effects we have been discussing, we now log-linearize its main equations. This will enable us to examine the impact of changes in the search parameters $c, k$ and $\gamma$, and of variations in the present discounted value of profits before repayment of the debt, on equilibrium credit and labor market tightness. We proceed under the simplifying assumption that the discount rate $r$ is zero.

Call $\Pi=(y-\omega) /(r+s)=(y-\omega) / s$ the expected present discount value of profits at the time the firm meets its worker. Denote by $\hat{x}$ the log-differential

\footnotetext{
${ }^{33}$ It is straightforward but cumbersome and uninstructive to generalize this characterization of quantitative comparative statics to the case $r>0$.
} 
of a variable $x$, i.e., $\hat{x}=d \log x$. Call $\epsilon$ and $\eta$ the elasticities of the credit and labor matching functions:

$$
\epsilon=-\frac{p^{\prime}(\phi) \phi}{p(\phi)}, \quad \eta=-\frac{q^{\prime}(\theta) \theta}{q(\theta)} .
$$

Under the assumptions we have made on the matching functions, $\epsilon \in(0,1)$ and $\eta \in(0,1)$. Elementary algebraic manipulations of equation (3.9.9. proposition 'ill changes in $c, k, \gamma$ and $\Pi$ when $r=0$ :

$$
\hat{\theta}=\frac{1}{\eta}\{(1+\mu) \hat{\Pi}-\mu[\epsilon \hat{k}+(1-\epsilon) \hat{c}]-\hat{\gamma}\}
$$

where

$$
\mu=\frac{B_{1}}{\beta \Pi-B_{1}}=\frac{q(\theta)}{q(\bar{\theta})}-1 \geq 0,
$$

is a measure of credit market tightness - i.e., a measure of the departure of equilibrium labor market tension from the Pissarides model. $\mu$ ranges from 0 when $\theta=\bar{\theta}$ (no credit frictions) to $+\infty$ when credit frictions go to infinity and $\theta$ goes to zero.! - -

We conclude that:

- The elasticity of equilibrium labor market tightness with respect to the present discounted value of profits is $(1+\mu) / \eta>1$. Credit market frictions thus multiply the effect of changes in profits on labor market tightness relative to the Pissarides case $(\mu=0)$. The coefficient $1+\mu$ measures the profit multiplier we have exhibited in figure $\overline{1}$ i.

- The elasticity of $\theta$ with respect to the search cost of banks $k$ is $-\mu \epsilon / \eta$, while its elasticity with respect to the credit search cost of firms is $-\mu(1-\epsilon) / \eta$. Both elasticities are negative: credit frictions slacken the labor market. These elasticities are larger in absolute value the tighter the credit market.

- The elasticity of $\theta$ with respect to the labor search cost $\gamma$ is exactly the same, $-1 / \eta$, as in the Pissarides model.

\footnotetext{
${ }^{34}$ Alternatively, we could use both $\left({ }_{13} \cdot \overline{9}\right)$ ) and $\left(\overline{3} \cdot \overline{1} \overline{0}^{\prime}\right)$.

${ }^{35}$ Alternatively, one can rewrite $\mu$ as a function of $\phi: \mu=G(\phi) /[\Pi-G(\phi)]$, where $G(\phi)=\frac{1}{1-\beta} \frac{c}{p(\phi)}=\frac{1}{\beta} \frac{k}{\phi p(\phi)}$ is the expected cost of credit frictions; $\mu$ depends positively on $G(\phi)$.
} 
Using equation (13i), the unemployment rate $u$ responds to changes in $\theta$ according to:

$$
\hat{u}=-(1-u)(1-\eta) \hat{\theta} .
$$

As in the Pissarides model, the proportional effect of labor market tightness on the unemployment rate depends on the level of employment - a reflection of the convexity of the Beveridge curve. Combining equations (4. (14.21) tells us how the equilibrium unemployment rate responds to changes in profits and search costs:

- The elasticity of $u$ with respect to $\Pi$ is $-(1-u)(1+\mu)(1 / \eta-1)<0$.

- The elasticity of $u$ with respect to $k$ is $-(1-u) \mu \epsilon(1 / \eta-1)<0$, while its elasticity with respect to $c$ is $-(1-u) \mu(1-\epsilon)(1 / \eta-1)<0$. These elasticities are larger in absolute value the larger the employment rate.

- The elasticity of $u$ with respect to $\gamma$ is $-(1-u)(1 / \eta-1)<0$.

Finally, define the internal rate of return of loans to firms, as the interest rate $R$ that equalizes the expected discounted value of the loan $\frac{\gamma}{R+q(\theta)}$ and the expected discounted repayment on the loan $\frac{q}{R+q(\theta)} \frac{\rho}{R+s}$. Using proposition ㅁ., we find that

$$
R-r=\beta(r+s) \mu \text {. }
$$

The excess return $R-r$ on business loans is increasing in $\beta$ (the share of the bank) and in $\mu$ (credit market imperfections). Credit market imperfections affect the excess return on commercial paper by increasing the duration of the (costly) first stage, and by increasing the cost of credit (and therefore $\mu)$. Finally, an increase in the destruction probability $s$ increases $R$ by decreasing the expected length of the repayment period.

\subsection{Calibration}

To get a feel for the equilibrium levels predicted by our model, we now adopt the following parameterizations for matching functions:

$$
\begin{aligned}
q(\theta) & =q_{0} \theta^{-\eta} \\
p(\phi) & =p_{0} \phi^{-\varepsilon},
\end{aligned}
$$




\begin{tabular}{l|ccc}
\hline \hline$u(\%)$ & Credit & $p_{0}=+\infty$ & $p_{0}=1$ \\
\hline Labor & & & \\
$q_{0}=1.5$ & & 5.6 & 9.3 \\
$q_{0}=1.1$ & & 9.9 & 16.0 \\
\hline
\end{tabular}

Table 1: Equilibrium unemployment

where $q_{0}$ and $p_{0}$ are (scale) measures of the intensity of the matches in labor and credit markets.

Table $]_{1}^{1}$ reports equilibrium unemployment rates in four different cases that correspond to all possible combinations of "high" and "low" credit and labor market frictions $36 !$

Traditional explanations (purely based on labor market imperfections) rely on a high degree of mismatch on the labor market, as measured by $q_{0}$, to explain high unemployment: this is the first column of our table. Our model suggests an alternative perspective, provided instead by the first row of table I: high unemployment could well be the result of a combination of labor and credit frictions that are both moderate. Indeed, for the parameters of the northeastern cell of the table, it takes about one year to find a credit line, and eight months to recruit a worker. Total pecuniary credit costs 15 , measured by $k / \phi p(\phi)$, represent $7 \%$ of total discounted output $y /(r+s)$. Equivalently, flow pecuniary credit costs $\mathcal{B} k$ represent $5.3 \%$ of annual GDP. Furthermore, the multiplier $1+\mu$ equals 1.74 , so that the elasticities of tightness to profits $\Pi$, and search costs $c$ or $k$, and $\gamma$ are respectively, using

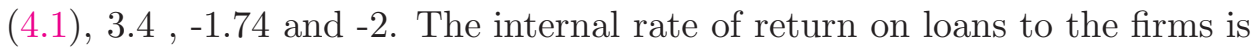
$22.4 \%$ a year, i.e. an excess return of $17.4 \%$ over the riskless rate $r=5 \%$. In other terms, the internal rate of return on loans is $17.4 \%$ higher than it would be absent credit market imperfections - which we view as an improvement over the standard calibration of the matching model.

\footnotetext{
${ }^{36} \beta=0.5 ; \gamma=1.5 ; y=1 ; s=0.15 ; r=0.05 ; c=0.35 ; k=0.35 ; \eta=0.5 ; \varepsilon=0.5 ; w=$ 0.66 .

${ }^{37}$ I.e., excluding the "sweat cost" for the entrepreneur of finding a financier.

${ }^{38}$ Using the formula $\mathcal{B} \phi p(\phi)=(1-u) s$, we get $\mathcal{B} k /[y(1-u)]=[s k / y] \phi p(\phi)=[.15 \times$ $.35 / 1] \times 1=5.3 \%$.
} 


\section{Monetary policy}

To study the effects of monetary policy on liquidity and unemployment, now assume that the financiers' opportunity cost of funds differs, for some reason that we do not model, from that of the entrepreneurs, and think of monetary policy as a way of affecting the opportunity cost of banks.

Denote by $r^{*}$ the discount rate of banks in the first and second stages of their life, and by $r^{* *}$ their discount rate in the third stage. Assume all other agents discount the future at their psychological rate $r$, and that $r^{*}<r$. The Bellman equations become:

$$
\begin{aligned}
r^{*} B_{0} & =-k+\phi p(\phi)\left(B_{1}-B_{0}\right)+\dot{B}_{0}, \\
r^{*} B_{1} & =-\gamma+q(\theta)\left(B_{2}-B_{1}\right)+\dot{B}_{1}, \\
r^{* *} B_{2} & =\rho+s\left(B_{3}-B_{2}\right)+\dot{B}_{2} . \\
r F_{0} & =-c+p(\phi)\left(F_{1}-F_{0}\right)+\dot{F}_{0}, \\
r F_{1} & =q(\theta)\left(F_{2}-F_{1}\right)+\dot{F}_{1}, \\
r F_{2} & =y-\omega-\rho+s\left(F_{3}-F_{2}\right)+\dot{F}_{2},
\end{aligned}
$$

Rewriting $F_{1}=\frac{q(\theta)}{r+q(\theta)} \frac{y-\rho-w}{r+s}$ and $B_{1}=\frac{-\gamma+q \frac{\rho}{r^{* *}+s}}{r^{*}+q(\theta)}$, Nash-bargaining over $\rho$ between firms and entrepreneurs now implies that

$$
\frac{F_{1}}{B_{1}}=\frac{1-\beta}{\beta} \frac{r^{* *}+s}{r+s} \frac{r^{*}+q(\theta)}{r+q(\theta)}
$$

Using the free-entry conditions to compute the backward-looking values of $B_{1}$ and $F_{1}$, and assuming (for simplicity and without much loss of generality) that $r^{* *}=r$, we find that

$$
\phi=\frac{k}{c} \frac{1-\beta}{\beta} \frac{r^{*}+q(\theta)}{r+q(\theta)}
$$

Note that $\phi$ now depends on the tightness of the labor market, so that the solution of our model loses its recursivity. But the interpretation of equation (1.7) remains straightforward: during the bargaining over $\rho$, the financiers are more patient $\left(r^{*}<r\right)$, and thus able to extract a higher effective share $\beta^{\prime}$ (with $\frac{1-\beta^{\prime}}{\beta^{\prime}}=\frac{1-\beta}{\beta} \frac{r^{*}+q(\theta)}{r+q(\theta)}$ ) of the total surplus of the financial relationship.

\footnotetext{
${ }^{39}$ If $r^{* *} \neq r$, then $\phi=\frac{1-\beta}{\beta} \frac{k}{c} \frac{r^{*}+q(\theta)}{r+q(\theta)} \frac{r^{* *}+s}{r+s}$.
} 


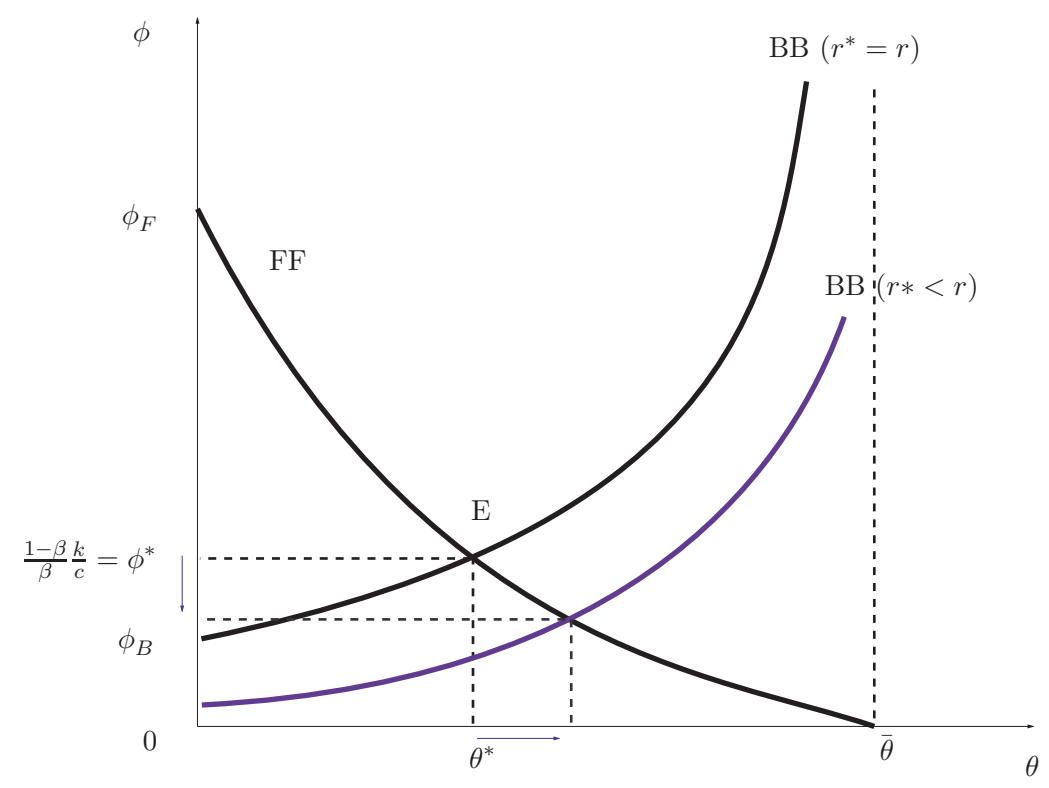

Figure 6: Impact of looser monetary policy

$\beta^{\prime}$ increases with $\theta$, because entrepreneurs must search for workers longer in a tighter labor market. This longer duration hurts bankers less in relative terms since they discount the future at a lower rate.

Recalculating the BB and the FF curves, one finds after a few manipulations:

$$
\begin{aligned}
\frac{k}{\phi p(\phi)} & =\beta \frac{q(\theta)}{r^{*}+q(\theta)}\left\{\frac{y-\omega}{(r+s)}-\frac{\gamma}{q(\theta)}\right\}, \\
\frac{c}{p(\phi)} & =(1-\beta) \frac{q(\theta)}{r+q(\theta)}\left\{\frac{y-\omega}{(r+s)}-\frac{\gamma}{q(\theta)}\right\} .
\end{aligned}
$$

The FF curve, which is the indifference curve of entrepreneurs, is independent of the monetary policy parameter $r^{*}$, but the location of BB curve of course depends on $r^{*}$. Looser monetary policy (a decrease in $r^{*}$ ) thus shifts the $\mathrm{BB}$ curve down and to the right, but leaves FF unchanged. In equilibrium, depicted in figure $\mathbf{6}_{-1}^{\prime}$ this lowers $\phi$ and raises $\theta$, slackening the credit market and reducing the unemployment rate. These are indeed the typical, almost textbook, effects of looser monetary policy - presented in our FF/BB framework.

Two remarks are in order. First, monetary policy has a direct impact on 
credit market tightness, and credit market tightness is transmitted to the labor market through a change in the creation rate of new firms, as was suggested in introduction. Second, monetary policy is more effective (given labor market frictions) in stimulating the economy when credit market frictions are high. This is quite intuitive: decreasing the opportunity cost of credit has more impact when the total cost of screening is high. Graphically, the BB curve is flatter and the FF curve steeper when the efficiency of the credit matching function is lower. Formally, a straightforward computation of the semi-elasticity of labor market tightness to the interest rate faced by banks yields, when $r=0$,

$$
\frac{\partial \hat{\theta}}{\partial r^{*}}=\frac{\mu}{1+\mu} \frac{\epsilon}{\eta} \frac{\Pi}{\gamma}
$$

Given $\Pi$ and $\gamma$ and labor frictions, a larger $\mu$ (i.e., a larger departure from the Pissarides equilibrium stemming for larger credit frictions $p_{0}$ ) is associated with a more effective monetary policy.1.!

\section{Endogenous wage}

We have so far assumed that the wage paid to workers was exogenous. We now examine what happens in the more general, and probably more realistic case where the wage is negotiated between workers and entrepreneurs.

Endogenous wages gives rise to "ménage à trois" between workers, entrepreneurs and bankers: all three parties have a stake in the firm, yet they only meet and negotiate pairwise. This gives an incentive to the parties who bargain first (the financier and the entrepreneur) to anticipate in their financial dealings the later arrival of workers in the firm. Debt thus becomes a strategic instrument that financiers and entrepreneurs can use to affect the wage that workers will eventually negotiate with their employer.

\footnotetext{
${ }^{40}$ By contrast, one can show that for given credit frictions, and given $\epsilon$ and $\eta$, a more efficient labor matching function (i.e., a higher $q_{0}$ ) has no impact on the semi-elasticity of labor market tightness to the interest rate.

41 The use of debt as a device to decrease the share of workers has been studied empirically and formalized theoretically by Bronars and Deers (1991) and Perotti and Spier (1993). The existence of this problem is recognized by Caballero and Hammour (1998), but assumed away by the assumption of block bargaining (workers vs. bankers and entrepreneurs). Our assumption of sequential bargaining seems more natural.
} 


\subsection{Sequential bargaining}

There are now two types of contracts in our economy: loan contracts negotiated between financiers and entrepreneurs, and wage contracts bargained between entrepreneurs and workers. We assume that these contracts are negotiated sequentially. The loan contract is first struck in stage 1, when financier and entrepreneur meet. The wage contract is then negotiated in stage 2 when entrepreneur and worker find each other. Entrepreneurs and workers take as given the loan contract which was written before they met. Bankers and entrepreneurs know that the result of their financial bargaining will influence the terms of the eventual labor contract.

\subsubsection{Wage bargaining}

We start with a description of wage bargaining between entrepreneur and worker, given the terms of the financial contract $\rho$ struck earlier between the entrepreneur and her financier.

Let $W$ denote the value for a worker of being employed, $U$ the value of being unemployed, and $b$ unemployment benefits. Then $W$ and $U$ satisfy the following Bellman equations:

$$
\begin{aligned}
r W & =\omega+s(U-W)+\dot{W}, \\
r U & =b+\theta q(\theta)(W-U)+\dot{U},
\end{aligned}
$$

since $\theta q(\theta)$ is the probability that an unemployed worker will get out of the unemployment pool by finding a job. Assume that entrepreneur and worker share the surplus $\left(F_{2}-F_{0}\right)+(W-U)$ generated by their relationship according a general Nash bargaining rule_t2! Then

$$
\omega=\arg \max \left(F_{2}-F_{0}\right)^{\alpha}(W-U)^{1-\alpha},
$$

where $\alpha \in(0,1)$ measures the bargaining power of the entrepreneur in the labor relationship.

This enables to prove:

\footnotetext{
${ }^{42}$ We could an alternatively assume that the outside option of the firm during bargaining is $F_{1}$, which would mean that the relation banker-entrepreneur is preserved in case of a separation. However, in that case, the financier would have to start again paying the recruitment $\operatorname{cost} \gamma$. Knowing, she might prefer to credibly commit ex-ante to withdraw from the relationship in such a case, which brings us back to our specification.
} 
Proposition $\mathbf{5}$ The wage schedule in any individual firm is given by

$$
\omega=\alpha(y-\rho)+(1-\alpha) U
$$

Proof. The first-order condition for an optimal surplus sharing is, using the exit condition

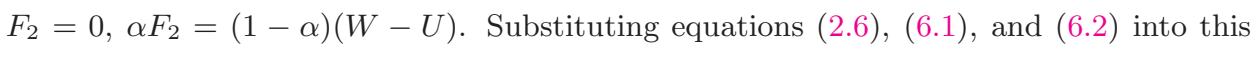
first-order condition yields the expression in the proposition.

The larger the firm's output net of repayment to the financier, the larger the wage. The more pleasant the prospect of unemployment looks to the worker (i.e., the larger $U$ ), the larger the wage must be. If workers have all the bargaining power $(\alpha=1)$, they extract all the surplus of the relationship by claiming what is left of output once the financier has been repaid $(w=y-\rho)$. If workers have no bargaining power, they are just paid the annuity value of the utility they would get if they were unemployed $(w=r U)$.

We will need below the following characterization of the effect of the repayment $\rho$ on the wage contract in the firm - a crucial effect since it will be taken into account by financier and firm in their negotiation over $\rho$ :

Corollary 1 A unit increase in repayments to the firm's financier decreases the wage by $\alpha$ (i.e., $\partial \omega / \partial \rho=-\alpha$ ).

The more the entrepreneur has promised to repay its financier, the smaller the total surplus that remains available to the firm and its worker. Since the workers get all the surplus when they have all the bargaining power $(\alpha=1)$, it is in such a case that an increased repayment to the banker affects them most.

\subsubsection{Loan bargaining}

Since the loan contract between financier and entrepreneur is written before the entrepreneur meets his worker, banker and entrepreneur take into account the effect of the bargain they strike now on the later negotiation between entrepreneur and worker. While it is still true that $\rho$ is

$$
\rho=\arg \max \left(B_{1}-B_{0}\right)^{\beta}\left(F_{1}-F_{0}\right)^{1-\beta},
$$

the outcome of bargaining is now given by: 
Proposition 6 The financial contract between financier and entrepreneur is

$$
\rho=\beta^{\prime \prime}(y-\omega)+\left(1-\beta^{\prime \prime}\right)(r+s) \frac{\gamma}{q(\theta)}
$$

where $\beta^{\prime \prime}=\beta /[1-\alpha(1-\beta)]>\beta$.

Proof. Using corollary the keep track of the effect of $\rho$ on the firm's future wage, the first-order condition for optimal sharing of the surplus is, using the exit conditions $B_{0}=F_{0}=0$ :

$$
\left(1-\beta^{\prime \prime}\right) B_{1}=\beta^{\prime \prime} F_{1} .
$$

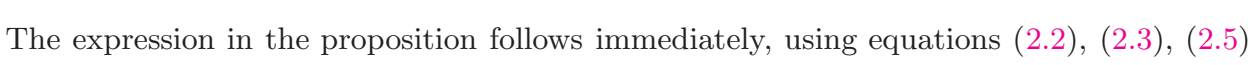

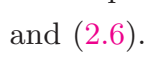

The equilibrium Nash-bargaining loan contract is similar to the one described by proposition ' that it is now the the effective bargaining power $\left(\beta^{\prime \prime}, 1-\beta^{\prime \prime}\right)$ of banker and entrepreneur which matters for the wage contract.

Equations for equilibrium wages and equilibrium $(\theta, \phi)$ are derived in the appendix.

\subsection{Workers' expropriation and firms' participation con- straints}

The remarkable feature of proposition $\overline{6}$ is that the workers' bargaining power affects, in our two-stage negotiating process, the effective bargaining power of firms and banks. When workers have no bargaining power, and only then, they get their reservation wage (the unemployment benefit $b$ ) regardless of the financial contract $\rho$. ' 13 ! The wage is then for all intents and purposes exogenous, with the result that financiers and entrepreneurs share their surplus according the shares $\beta, 1-\beta$, since $\beta^{\prime \prime}=\beta$ when $\alpha=0$. However, when the wage is affected by $\rho$ because workers have the muscle to obtain a share of net profits $y-\rho$, the two stage bargaining process $d e$ facto strengthens the bargaining power of the banker, as he will then claim a share $\beta^{\prime \prime}>\beta$ of the surplus of the financial relationship.

\footnotetext{
${ }^{43}$ See equation (1י.'.
} 
This raises the following difficulty. We have so far assumed that entrepreneurs borrow exactly $\gamma$ per unit of time, and repay the corresponding $\rho$. However, since increasing the value of $\rho$ is a way to decrease the share of workers in the wage bargaining problem, it is in the interest of both bankers and firms to use debt as a strategic variable to expropriate workers, and to stipulate a flow loan larger than $\gamma$ and, accordingly, a repayment larger than $\rho$. In point of fact, the cash flow from financier to entrepreneur should rise beyond $\gamma$ up to the point where wages have been reduced to their reservation level $b ! !_{-}^{1} 4 !_{-}$We should however not forget that, in more general settings, debt has disincentive effects on the recruiting efforts of the entrepreneurs. We must check that the introduction of these disincentive effects into our model would not overturn its results.

Imagine therefore, to simplify, that the entrepreneur searches for a worker if finding a worker does not lower the firm's expected value:

$$
\frac{q(\theta)}{r+q(\theta)} F_{2}-F_{1} \geq 0
$$

It is straightforward to show that this incentive compatibility constraint for firms implies that the flow amount, call it $z$, that a financier will lend to an entrepreneur cannot exceed the job search cost: $:_{-}^{45 !}$

$$
z \leq \gamma
$$

The rationing of credit that is required to give the entrepreneur the incentive to search thus limits the use of debt as a strategic instrument to expropriate workers. In equilibrium, one can show that the incentive compatibility constraint is binding. As a result, the equilibrium flow loan is exactly $z=\gamma$, and the wage remains higher than the reservation level $b$. In other words, the financial contract $(\gamma, \rho)$ we have described for exogenous wages is the incentive compatible equilibrium under endogenous wages.

\footnotetext{
${ }^{44}$ This reasoning of course presupposes either that the entrepreneur has consumed right away the resources lent to her by the financier above and beyond what was needed to search for a worker, or, if she has not, that she has protected them so they cannot be part of the negotiation with the workers.

${ }^{45}$ Use the modified Bellman equation for the firm $r F_{1}=z-\gamma+q(\theta)\left(F_{2}-F_{1}\right)$ together with the incentive compatibility constraint.
} 


\section{Empirical investigation}

One of the major empirical predictions of our model is embodied in equation (3.1) which reflects the link between equilibrium labor market tightness and financial frictions (as summarized by costs $c$ and $k$ ). To make this equation more testable, we express its implications for equilibrium unemployment

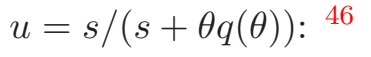

$$
\frac{u-\bar{u}}{\bar{u}}=\frac{1-\eta}{\eta} \frac{\text { Financial costs }}{\Pi}
$$

For instance, if matching function in the credit market were Cobb-Douglas, 14 we would get:

$$
\frac{u-\bar{u}}{\bar{u}}=\frac{1-\eta}{\eta} \frac{\frac{1}{p_{0}} \frac{k^{\varepsilon} c^{1-\varepsilon}}{\beta^{\varepsilon}(1-\beta)^{1-\varepsilon}}}{\Pi} .
$$

$\bar{u}$ is the unemployment rate that would prevail, due to frictions on the labor market, in the absence of credit imperfections (the Pissarides unemployment rate). Equation ( $\left.\overline{7}_{1}^{-} \bar{l}_{1}\right)$ states that deviations of unemployment away from $\bar{u}$ are increasing in financial frictions and decreasing in aggregate profits (which reflect cyclical factors).

We therefore estimate, after linearization, a dynamic version of equation $\left(\overline{\overline{1}} \cdot \overline{1} \overline{1}_{1}^{\prime}\right)$ :

$$
u_{i t}=D_{i}+b_{u} \cdot u_{i, t-1}+b_{c} \cdot c y c l e_{i t}+b_{v c} \cdot v c_{i t},
$$

where $D_{i}$ reflects country-specific frictional factors on the labor market, $b_{u}$ characterizes the short-run dynamic of unemployment, and cyclical factors are captured by $b_{c \cdot 1}^{48 !}$ The Frish-Waugh interpretation of the regression is that $b_{v c}$ reflects the impact of venture capital investments net of cyclical factors like profits - in other words, the impact of the (negative of) financial imperfections. In this sense, $b_{v c}$ measures the short-run impact of venture capital, while $b_{v c} /\left(1-b_{u}\right)$ estimates the long-run impact of a permanent change in venture capital, and $D_{i} /\left(1-b_{u}\right)$ gauges the equilibrium rate of unemployment controlling for cyclical indicators and financial market imperfections. We use the least-square dummy variable estimator, treating the fixed effects $D_{i}$ as parameters.

\footnotetext{
${ }^{46}$ We linearize around $\bar{\theta}$ and $\bar{u}=s /(s+\theta q(\bar{\theta}))$, we neglect quadratic terms in $u^{2}$ and we use the definition of $\bar{\theta}: \gamma / q(\bar{\theta})=\Pi$.

${ }^{47}$ This example is only illustrative.

${ }^{48}$ Regressions with the logarithm of unemployment instead as dependent variable gave very similar results.
} 


\subsection{Data description}

We build a panel of OECD countries using two sources of data. First, some usual macroeconomic indicators on unemployment, aggregate investment, real and nominal GDP were compiled from the OECD national accounts and labor force statistics. These data cover the period 1960-1999. Second, we used data on venture capital published in Jeng and Wells (1998, pp64-65, tables 11-12). As they very carefully report it, venture capital investment is the sum of start-up, seed and expansion investment. Early stage investment, which we find to be the most significant variable, is defined as the sum of start-up and seed. These data are used to construct an unbalanced panel covering the period 1986-1995 for 20 OECD countries. In three countries, New Zealand, Australia and Japan, the number of observation was only 3 or 4 , and accordingly, these countries were removed from our sample. German aggregate indicator were not consistent over the period due to reunification, and Germany was also taken out. In the end, we build a panel with the 16 following countries: the US, Canada, the UK, Ireland, France, Spain, Italy, Portugal, the Netherlands, Belgium, Austria, Switzerland, Finland, Norway, Sweden and Denmark. All countries thus have 10 venture capital observations, except Norway and Finland (8 observations). The total number of observations in the panel is thus 156. Each lag in the specification removes 16 observations, and accordingly, our baseline regression will have 140 observations.

\section{$7.2 \quad$ Results}

We try several cyclical controls and several specifications. All specifications include lagged unemployment in the regressors. Tables cyclical control (real GDP growth in table 2 and investment/GDP ratio in table 1 is). Columns 1 to 7 of each table include country specific effects. Columns 1, 2 and 3 try different specifications (with possibly a lag on the cyclical control, and with the lagged venture capital variable, or including both the contemporaneous and the lagged venture capital variable). Our preferred specification includes contemporaneous and lagged variables, and is reported in column 4 . Columns 5 to 9 test the robustness of this specification: notably, columns 5 to 7 add common time effect, country specific trends or both. Columns 8 and 9 impose a common constant instead of the country fixed effects, with or without time effect. 
As it can be seen from all columns between 1 and 7 in table 13, our lagged venture capital variable is always negative and significant at the $1 \%$ level, whereas the current venture capital variable is never significant. This suggests the presence of a time-to-build period or, consistent with our search theory, a time-to-recruit period between investment and the decrease in unemployment. The Durbin-Watson statistics are generally very close to $2.49 !$ In columns 8 and 9 , the coefficient on lagged venture capital is significant at the $10 \%$ level ( 7 and 9\%), whereas the Durbin-Watson statistics are less satisfactory, around 1.5.

We find similar results when we control for aggregate investment in table i. In columns 3 to 7, the Durbin-Watson statistics are slightly smaller than before, around 1.7 or 1.8, but still satisfactory. Lagged venture capital is slightly less significant, but our preferred specification 4 still achieves significance at the $5 \%$ level.

There thus seems to be a quite robust negative correlation between lagged venture capital investment and unemployment. To measure the magnitude of the effect, we can calculate the short-run effect of a one standard deviation (0.075) in the venture capital to GDP ratio, as well as the long-run effect of a permanent one standard deviation increase. Table $22_{-1}^{2}$ shows the unemployment effects corresponding to our different specifications.

\begin{tabular}{l|cccccc}
\hline \hline Specification & B3 & B4 & B5 & D3 & D4 & D5 \\
\hline Short-run & -0.25 & -0.28 & -0.28 & -0.24 & -0.20 & -0.15 \\
Long-run & -2.40 & -2.10 & -2.50 & -0.90 & -0.91 & -0.63 \\
\hline
\end{tabular}

Table 2: Short run and long run effects

The coefficient on lagged venture capital is always estimated in the same range (around -3.3), and accordingly the short run impact is rather similar across specifications: it corresponds to a reduction in unemployment around $0.25 \%$ of the labor force. In the long run, the impact hinges on the coefficient $b_{u}$ whose estimates depend more strongly on the cyclical control; accordingly, this effect ranges in, say, 0.9 to 2.5 percent of the labor force.

Next, table

\footnotetext{
${ }^{49}$ The Durbin-Watson-Savin-White time series test for autocorrelation of residuals, if applied without caution to our panel, would never reject the null of no autocorrelation. We are however unaware of any available tests for panels.
} 
investments are the really important variable: controlling for continuation investment does not change the significance of early stage venture capital. Continuation investment is never significant.

Our empirical study therefore indicates that important determinants of unemployment are to be found outside the labor market: notably, as the model had suggested, credit market conditions are particularly relevant.

\section{Conclusion}

This paper has set the foundations of a simple macroeconomic model of credit and labor market imperfections based on matching frictions. Our framework generates comparative statics reminiscent of the IS/LM model, and shows that labor and credit market imperfections interact in a complementary way. This may explain why European and US unemployment rates still differ so much in spite of increased similarity at the margin of their labor markets. It also provides a rationalization of the common opinion that labor market structure is not solely responsible for the remarkable US growth performance.

Our paper leaves open a number of questions, both theoretical and empirical. First, what would happen if entry into banking or entrepreneurship were not instantaneous - i.e., what would happens if the long run were not reached immediately as in our paper? Second, what if liquidity not only meant willingness to lend, but also existence of sufficient financial resources to finance economic activity? Third, what additional empirical evidence could be adduced to back up our claim that the combination of moderate credit frictions and moderate labor frictions might be enough to explain high unemployment?

Answering the first question is easy-it suffices to modify the free entry conditions - and required to meaningfully formalize the dynamic response of labor and credit markets to outside shocks and their behavior over the business cycle.

Dealing with the second issue would enable us to "close" our model in a more traditional way, to study in our setup whether the economy generates enough liquidity in the face of shocks to finance itself without outside intervention,, 501

\footnotetext{
${ }^{50}$ This is one of the main question asked by Holmström and Tirole (1998).
} 
and to generate a mechanism for the propagation and transmission of shocks over time.

Finally, the search for empirical evidence on credit frictions figures, first and foremost, on our research agenda. Some data on gross credit flows have been compiled recently by Dell'Ariccia and Garibaldi (1999) _ for the US. A cross country extension of their data set could be used to provide additional corroboration of our story on high unemployment.

\section{Appendix: endogenous wages}

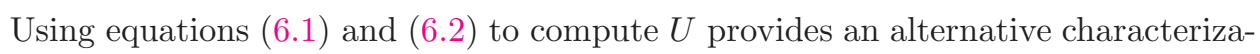
tion of the optimal wage contract described in proposition

$$
\omega=\alpha_{\theta}(y-\rho)+\left(1-\alpha_{\theta}\right) b
$$

where

$$
\alpha_{\theta}=\alpha \frac{r+s+\theta q(\theta)}{r+s+\alpha \theta q(\theta)} .
$$

The weight $\alpha_{\theta}$ increases from $\alpha$ to 1 when $\theta$ ranges from 0 to $\infty$ : higher tightness increases workers' outside options and increase the share $\alpha_{\theta}$ of the profits net of repayment they get. In the limit $\theta \rightarrow+\infty$, workers' outside option is the same as their current net value, and they capture all the surplus $\left(\alpha_{\theta} \rightarrow 1\right)$.

With this expression in hand, we are ready to characterize the equilibrium with endogenous wages:

Proposition 7 Equilibrium credit market tightness $\phi$ and labor market $\theta$ are the solution to the pair of equations

$$
\begin{gathered}
\frac{k}{\phi p(\phi)}=\beta^{\prime \prime}\left(1-\sigma_{\theta}\right) \frac{q(\theta)}{r+q(\theta)}\left(\frac{y-b}{r+s}-\frac{\gamma}{q(\theta)}\right) \\
\frac{c}{p(\phi)}=\left(1-\beta^{\prime \prime}\right)\left(1-\sigma_{\theta}\right) \frac{q(\theta)}{r+q(\theta)}\left(\frac{y-b}{r+s}-\frac{\gamma}{q(\theta)}\right)
\end{gathered}
$$

\footnotetext{
${ }^{51}$ Their paper, of which we were made aware after writing ours, focuses solely on the credit market but it does use a matching model of credit to try to rationalize observed gross credit flows.
} 


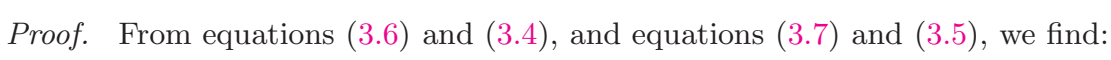

$$
\begin{aligned}
B_{1} & =-\frac{\gamma}{r+q(\theta)}+\frac{q(\theta)}{r+q(\theta)} \frac{\rho}{r+s} \\
F_{1} & =\frac{q(\theta)}{r+q(\theta)} \frac{y-\omega-\rho}{r+s} .
\end{aligned}
$$

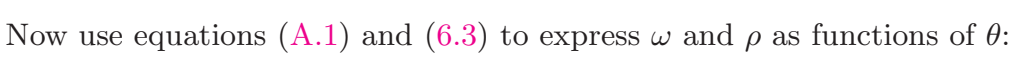

$$
\begin{aligned}
\omega & =\sigma_{\theta}\left[y-(r+s) \frac{\gamma}{q(\theta)}\right]+\left(1-\sigma_{\theta}\right) b \\
\rho & =\mu_{\theta}(y-b)+\left(1-\mu_{\theta}\right)(r+s) \frac{\gamma}{q(\theta)},
\end{aligned}
$$

where $\sigma_{\theta}=\left[\alpha_{\theta}\left(1-\beta^{\prime \prime}\right)\right] /\left[1-\alpha_{\theta} \beta^{\prime \prime}\right]$ and $\mu_{\theta}=\left(1-\sigma_{\theta}\right) \beta^{\prime \prime}$. Inserting these expressions into equations (A.2) and (A) and equating the resulting formulas with the values $B_{1}$ and

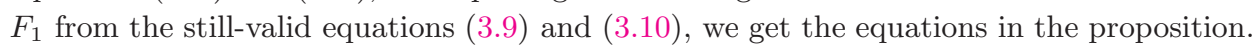

\section{References}

[1] Aghion, P., Bacchetta, P., and Banerjee A., "Capital Markets and the Instability of Open Economies". Mimeo.

[2] Bernanke, B., and Gertler, M. (1989). "Agency Costs, Net Worth and Business Fluctuations". American Economic Review, 79, 14-31.

[3] Blanchflower, D.G., and Oswald, A. (1998). "What makes an Entrepreneur?" Journal of Labor Economics, vol. 16, 26-60.

[4] Blanchard, O.J., and Muet, A. (1993). "Competitiveness through Disinflation: an Assessment of French Macroeconomic Policy since 1983". Economic Policy 16, April, 12-56.

[5] Bronars, S.G., and Deere D.R. (1991). "The Threat of Unionization, the Use of Debt, and the Preservation of Shareholder Wealth". The Quarterly Journal of Economics, February, 231-254.

[6] Caballero, R., and Hammour, M.L. (1998). "Improper Churn: Social Costs and Macroeconomic Consequences". NBER WP 6717.

[7] Dell'Ariccia, G. and Garibaldi, P. (1999). "Gross Credit Flows", mimeo, IMF.

[8] den Haan, W., Ramey, G., and Watson, J. (1999). "Liquidity Flows and Fragility of Business Enterprises." NBER WP 7057.

[9] Diamond, P. (1981). "Mobility Costs, Frictional Unemployment and Efficiency". Journal of Political Economy, vol. 89(4), 798-812. 
[10] Diamond, P. (1990). "Pairwise Credit in Search Equilibrium". The Quarterly Journal of Economics, May, 285-319.

[11] Easterly, W., Islam, R., and Stiglitz, J. (1999). "Shaken and Stirred:Volatility and Macroeconomic Paradigms for Rich and Poor Countries". Michael Bruno Memorial Lecture, XIIth World Congress of the IEA, Buenos Aires.

[12] Freixas, X. and Rochet, J.-C. (1997). Microeconomics of Banking. The MIT Press.

[13] Jeng, L. and Wells, P. (1998) "The Determinants of Venture Capital Financing: Evidence Across Countries". Boston University.

[14] Gertler, M. and Gilchrist, S. (1994). "Monetary Policy, Business Cycles, and the Behavior of Small Manufacturing Firms". The Quarterly Journal of Economics, May, 309-340.

[15] Holmström, B. and Tirole, J. (1998) "Private and Public Supply of Liquidity". Journal of Political Economy, February, 1-40.

[16] Mortensen, D.T. and Pissarides, C.A. (1994). "Job Creation and Job Destruction in the Theory of Unemployment". Review of Economic Studies, 64, 397415.

[17] OECD (1994). "Employment Outlook". Chapter 3, 103-135.

[18] OECD (1999). "Employment Outlook".

[19] OECD (various years). "Job Studies".

[20] Perotti, E.C. and Spier, K.E. (1993). "Capital Structure as a Bargaining Tool: The Role of Leverage in Contract Renegociation". American Economic Review, December, 1131-1141.

[21] Pissarides, C.A. (1990). Equilibrium Unemployment Theory. Oxford, Basil Blackwell.

[22] Romer, C. and Romer, D. (1989) "Does Monetary Policy Matter? A New Test in the Spirit of Friedman and Schwartz". NBER Macroeconomics Annual 4, 121-170.

[23] Shapiro, K. and Stiglitz, J. (1984). "Equilibrium Unemployment as a Worker Discipline Device". American Economic Review, June, 74(3), 433-44.

[24] Stiglitz, J. and Weiss, A. (1981). "Credit Rationing in Markets with Imperfect Information". American Economic Review, June, 391-410. 
Table 3 : Unemployment impact of venture capital (controlling by GDP growth) ; dependent variable : unemployment ${ }^{\text {a }}$

\begin{tabular}{|c|c|c|c|c|c|c|c|c|c|}
\hline & (1) & (2) & (3) & (4) & (5) & (6) & (7) & (8) & (9) \\
\hline Unemployment rate (-1) & $\begin{array}{c}1.02 \\
(29.80)\end{array}$ & $\begin{array}{c}1.01 \\
(28.83)\end{array}$ & $\begin{array}{c}0.89 \\
(26.42)\end{array}$ & $\begin{array}{c}0.89 \\
(25.84)\end{array}$ & $\begin{array}{c}0.89 \\
(21.07)\end{array}$ & $\begin{array}{c}0.73 \\
(14.79)\end{array}$ & $\begin{array}{c}0.73 \\
(10.28)\end{array}$ & $\begin{array}{c}1.01 \\
(62.33)\end{array}$ & $\begin{array}{c}1.02 \\
(60.68)\end{array}$ \\
\hline GDP growth rate & $\begin{array}{c}-44.95 \\
(-17.21)\end{array}$ & $\begin{array}{c}-44.85 \\
(-16.90)\end{array}$ & $\begin{array}{c}-29.80 \\
(-10.03)\end{array}$ & $\begin{array}{c}-29.78 \\
(-10.09)\end{array}$ & $\begin{array}{l}-28.44 \\
(-6.19)\end{array}$ & $\begin{array}{l}-22.55 \\
(-7.12)\end{array}$ & $\begin{array}{l}-21.17 \\
(-4.25)\end{array}$ & $\begin{array}{c}-31.81 \\
(-10.10)\end{array}$ & $\begin{array}{l}-26.30 \\
(-5.92)\end{array}$ \\
\hline GDP growth rate (-1) & - & - & $\begin{array}{l}-20.69 \\
(-7.32)\end{array}$ & $\begin{array}{l}-20.82 \\
(-7.37)\end{array}$ & $\begin{array}{l}-21.15 \\
(-5.25)\end{array}$ & $\begin{array}{l}-24.63 \\
(-873)\end{array}$ & $\begin{array}{l}-27.29 \\
(-6.79)\end{array}$ & $\begin{array}{l}-15.98 \\
(-5.06)\end{array}$ & $\begin{array}{l}-17.53 \\
(-4.01)\end{array}$ \\
\hline Venture capital rate & - & $\begin{array}{c}0.03 \\
(\mathbf{0 . 0 3})\end{array}$ & - & $\begin{array}{c}0.57 \\
(0.71)\end{array}$ & $\begin{array}{c}0.27 \\
(0.28)\end{array}$ & $\begin{array}{c}0.13 \\
(0.14)\end{array}$ & $\begin{array}{c}-0.08 \\
(-0.07)\end{array}$ & $\begin{array}{c}-0.23 \\
(-0.24)\end{array}$ & $\begin{array}{c}0.36 \\
(0.32)\end{array}$ \\
\hline Venture capital rate (-1) & $\begin{array}{c}-4.15 \\
(-4.41)\end{array}$ & $\begin{array}{c}-4.15 \\
(-3.90)\end{array}$ & $\begin{array}{c}-3.38 \\
(-3.25)\end{array}$ & $\begin{array}{c}-3.79 \\
(-3.12)\end{array}$ & $\begin{array}{c}-3.78 \\
(-2.98)\end{array}$ & $\begin{array}{c}-3.65 \\
(-2.54)\end{array}$ & $\begin{array}{c}-3.70 \\
(-2.45)\end{array}$ & $\begin{array}{c}-2.29 \\
(-1.73)\end{array}$ & $\begin{array}{c}-2.54 \\
(-1.84)\end{array}$ \\
\hline Fixed country effects / constant & - & - & - & - & - & - & - & $\begin{array}{c}1.29 \\
(9.95)\end{array}$ & $\begin{array}{c}0.80 \\
(3.66)\end{array}$ \\
\hline USA & 1.06 & 1.08 & 1.91 & 1.92 & 1.63 & 2.76 & -2.82 & - & - \\
\hline CAN & 1.35 & 1.38 & 2.52 & 2.53 & 2.24 & -3.56 & -9.26 & - & - \\
\hline GBR & 1.04 & 1.07 & 2.15 & 2.19 & 1.90 & 2.20 & -2.30 & - & - \\
\hline IRE & 2.47 & 2.52 & 4.38 & 4.46 & 4.08 & 9.23 & 3.68 & - & - \\
\hline FRA & 1.18 & 1.21 & 2.49 & 2.54 & 2.22 & 7.54 & 2.61 & - & - \\
\hline SPA & 1.51 & 1.57 & 3.95 & 4.05 & 3.68 & -5.63 & -10.24 & - & - \\
\hline ITA & 0.89 & 0.93 & 2.35 & 2.41 & 2.07 & 18.37 & 13.17 & - & - \\
\hline POR & 1.77 & 1.79 & 2.59 & 2.60 & 2.30 & 4.24 & -0.85 & - & - \\
\hline $\mathrm{HOL}$ & 1.00 & 1.02 & 2.08 & 2.10 & 1.80 & -10.03 & -16.20 & - & - \\
\hline BEL & 1.90 & 1.93 & 3.13 & 3.19 & 2.88 & -8.87 & -13.67 & - & - \\
\hline DEN & 0.99 & 1.02 & 2.00 & 2.04 & 1.73 & 0.61 & -4.57 & - & - \\
\hline NOR & 1.75 & 1.76 & 3.38 & 2.39 & 2.04 & -11.50 & -19.54 & - & - \\
\hline SWE & 1.15 & 1.16 & 1.61 & 1.63 & 1.34 & -19.08 & -23.41 & - & - \\
\hline FIN & 2.09 & 2.12 & 3.23 & 3.26 & 2.92 & -69.01 & -72.36 & - & - \\
\hline AUT & 1.26 & 1.27 & 1.83 & 1.85 & 1.54 & 7.30 & 1.88 & - & - \\
\hline SWI & 1.07 & 1.07 & 1.35 & 1.36 & 1.08 & -2.10 & -6.96 & - & - \\
\hline Common time effects & No & No & No & No & Yes & No & Yes & No & Yes \\
\hline Country specific trends & No & No & No & No & No & Yes & Yes & No & No \\
\hline \multicolumn{10}{|l|}{ Weighted Statistics } \\
\hline $\mathrm{R}^{2}$ & 0.99 & 0.99 & 0.99 & 0.99 & 0.99 & 0.99 & 0.99 & 0.98 & 0.97 \\
\hline F-statistics & 6077.55 & 3864.46 & 4175.26 & 3328.53 & 674.54 & 932.82 & 444.65 & 1338.54 & 330.51 \\
\hline Durbin-Watson & 2.05 & 2.04 & 1.90 & 1.90 & 1.84 & 2.19 & 2.13 & 1.46 & 1.49 \\
\hline Number of observations & 140 & 140 & 140 & 140 & 140 & 140 & 140 & 140 & 140 \\
\hline
\end{tabular}

${ }^{\text {a }}$ Estimation method : Generalized Least Square Dummy Variables (with cross-section weights) ; t-statistics are in parentheses. 
Table 4 : Unemployment impact of venture capital (controlling by Inv/GDP); dependent variable : unemployment ${ }^{\mathrm{a}}$

\begin{tabular}{|c|c|c|c|c|c|c|c|c|c|}
\hline & (1) & (2) & (3) & (4) & (5) & (6) & (7) & (8) & (9) \\
\hline Unemployment rate (-1) & $\begin{array}{c}0.55 \\
(11.95)\end{array}$ & $\begin{array}{c}0.55 \\
(11.18)\end{array}$ & $\begin{array}{c}0.74 \\
(14.57)\end{array}$ & $\begin{array}{c}0.74 \\
(14.47)\end{array}$ & $\begin{array}{c}0.72 \\
(13.22)\end{array}$ & $\begin{array}{c}0.43 \\
(5.48)\end{array}$ & $\begin{array}{c}0.46 \\
(5.30)\end{array}$ & $\begin{array}{c}0.99 \\
(59.90)\end{array}$ & $\begin{array}{c}0.98 \\
(59.73)\end{array}$ \\
\hline INV / GDP & $\begin{array}{l}-51.34 \\
(-8.54)\end{array}$ & $\begin{array}{l}-51.51 \\
(-8.51)\end{array}$ & $\begin{array}{c}-86.91 \\
(-12.70)\end{array}$ & $\begin{array}{c}-87.01 \\
(-12.59)\end{array}$ & $\begin{array}{l}-77.17 \\
(-9.18)\end{array}$ & $\begin{array}{c}-84.05 \\
(-10.66)\end{array}$ & $\begin{array}{l}-80.51 \\
(-7.92)\end{array}$ & $\begin{array}{c}-71.90 \\
(-11.78)\end{array}$ & $\begin{array}{l}-60.67 \\
(-7.77)\end{array}$ \\
\hline (INV / GDP) (-1) & - & - & $\begin{array}{l}58.28 \\
(8.14)\end{array}$ & $\begin{array}{l}58.56 \\
(8.01)\end{array}$ & $\begin{array}{l}51.77 \\
(6.41)\end{array}$ & $\begin{array}{c}9.54 \\
(0.90)\end{array}$ & $\begin{array}{l}12.11 \\
(1.01)\end{array}$ & $\begin{array}{c}74.35 \\
(11.53)\end{array}$ & $\begin{array}{l}63.87 \\
(7.79)\end{array}$ \\
\hline Venture capital rate & - & $\begin{array}{c}-0.38 \\
(-0.28)\end{array}$ & - & $\begin{array}{c}0.06 \\
(0.04)\end{array}$ & $\begin{array}{c}0.32 \\
(0.22)\end{array}$ & $\begin{array}{c}-0.39 \\
(-0.29)\end{array}$ & $\begin{array}{c}0.16 \\
(0.11)\end{array}$ & $\begin{array}{c}-0.37 \\
(-0.26)\end{array}$ & $\begin{array}{c}0.11 \\
(0.08)\end{array}$ \\
\hline Venture capital rate (-1) & $\begin{array}{c}-5.11 \\
(-3.22)\end{array}$ & $\begin{array}{c}-4.92 \\
(-2.69)\end{array}$ & $\begin{array}{c}-3.22 \\
(-2.26)\end{array}$ & $\begin{array}{c}-3.29 \\
(-2.05)\end{array}$ & $\begin{array}{c}-2.70 \\
(-1.67)\end{array}$ & $\begin{array}{c}-2.00 \\
(-1.38)\end{array}$ & $\begin{array}{c}-2.15 \\
(-1.40)\end{array}$ & $\begin{array}{c}-2.70 \\
(-1.80)\end{array}$ & $\begin{array}{c}-2.67 \\
(-1.74)\end{array}$ \\
\hline Fixed country effects / constant & - & - & - & - & - & - & - & $\begin{array}{c}-0.07 \\
(-0.19)\end{array}$ & $\begin{array}{c}-0.34 \\
(-0.70)\end{array}$ \\
\hline USA & 11.49 & 11.54 & 6.41 & 6.37 & 5.70 & 12.70 & 15.05 & - & - \\
\hline CAN & 14.18 & 14.27 & 8.07 & 8.03 & 7.31 & 16.13 & 19.35 & - & - \\
\hline GBR & 13.06 & 13.12 & 7.31 & 7.26 & 6.55 & 23.21 & 23.22 & - & - \\
\hline IRE & 15.87 & 15.95 & 8.74 & 8.68 & 8.16 & 69.54 & 68.01 & - & - \\
\hline FRA & 16.06 & 16.13 & 9.19 & 9.14 & 8.40 & 23.33 & 24.53 & - & - \\
\hline SPA & 21.16 & 21.25 & 12.43 & 12.36 & 11.69 & -10.32 & -8.13 & - & - \\
\hline ITA & 15.06 & 15.12 & 8.54 & 8.49 & 7.87 & 46.51 & 47.05 & - & - \\
\hline POR & 16.79 & 16.87 & 9.78 & 9.73 & 6.49 & -12.45 & -9.13 & - & - \\
\hline $\mathrm{HOL}$ & 13.20 & 13.27 & 7.25 & 7.20 & 7.62 & 30.59 & 31.10 & - & - \\
\hline BEL & 13.99 & 14.05 & 8.32 & 8.28 & 7.12 & -16.06 & -13.35 & - & - \\
\hline DEN & 14.09 & 14.14 & 7.87 & 7.82 & 6.30 & 34.78 & 35.75 & - & - \\
\hline NOR & 13.53 & 13.58 & 7.16 & 7.11 & 5.99 & 70.26 & 68.61 & - & - \\
\hline SWE & 11.80 & 11.84 & 6.76 & 6.72 & 9.00 & 11.42 & 12.37 & - & - \\
\hline FIN & 17.21 & 17.28 & 9.77 & 9.72 & 7.33 & 26.74 & 23.83 & - & - \\
\hline AUT & 14.34 & 14.38 & 8.33 & 8.28 & 7.41 & -3.83 & -0.01 & - & - \\
\hline SWI & 14.70 & 14.75 & 8.48 & 8.43 & & -1.52 & 0.95 & - & - \\
\hline Common time effects & No & No & No & No & Yes & No & Yes & No & Yes \\
\hline Country specific trends & No & No & No & No & No & Yes & Yes & No & No \\
\hline \multicolumn{10}{|l|}{ Weighted Statistics } \\
\hline $\mathrm{R}^{2}$ & 0.98 & 0.98 & 0.97 & 0.97 & 0.97 & 0.99 & 0.99 & 0.96 & 0.97 \\
\hline F-statistics & 2629.66 & 1731.88 & 1438.53 & 1065.07 & 345.16 & 486.38 & 327.88 & 659.64 & 273.10 \\
\hline Durbin-Watson & 1.13 & 1.13 & 1.67 & 1.67 & 1.63 & 1.85 & 1.85 & 1.52 & 1.47 \\
\hline Number of observations & 140 & 140 & 140 & 140 & 140 & 140 & 140 & 140 & 140 \\
\hline
\end{tabular}

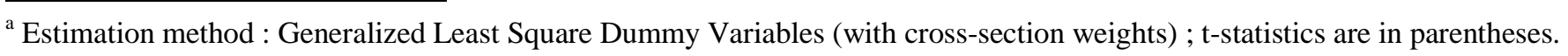


Table 5 : Comparison of different measures of venture capital ; dependent variable : unemployment ${ }^{\mathrm{a}}$

\begin{tabular}{|c|c|c|c|}
\hline & (1) & (2) & (3) \\
\hline Unemployment rate $(-1)$ & $\begin{array}{c}0.89 \\
(25.84)\end{array}$ & $\begin{array}{c}0.88 \\
(25.06)\end{array}$ & $\begin{array}{c}0.89 \\
(25.27\end{array}$ \\
\hline GDP growth rate & $\begin{array}{c}-29.78 \\
(-10.09)\end{array}$ & $\begin{array}{l}-28.21 \\
(-9.10)\end{array}$ & $\begin{array}{l}-29.54 \\
(-9.85)\end{array}$ \\
\hline GDP growth rate $(-1)$ & $\begin{array}{l}-20.82 \\
(-7.37)\end{array}$ & $\begin{array}{l}-23.46 \\
(-8.12)\end{array}$ & $\begin{array}{l}-20.88 \\
(-7.29)\end{array}$ \\
\hline Venture capital rate & $\begin{array}{c}0.57 \\
(0.71)\end{array}$ & - & $\begin{array}{c}0.54 \\
(\mathbf{0 . 6 6})\end{array}$ \\
\hline Venture capital rate $(-1)$ & $\begin{array}{c}-3.79 \\
(-3.12)\end{array}$ & - & $\begin{array}{c}-3.83 \\
(-2.94)\end{array}$ \\
\hline Continuation venture capital rate & - & $\begin{array}{c}-0.21 \\
(-0.78)\end{array}$ & $\begin{array}{c}-0.00 \\
(-0.00)\end{array}$ \\
\hline Continuation venture capital rate $(-1)$ & - & $\begin{array}{c}-0.05 \\
(-0.16)\end{array}$ & $\begin{array}{c}0.14 \\
(0.44)\end{array}$ \\
\hline Fixed effects / constant & - & - & - \\
\hline USA & 1.92 & 1.95 & 1.89 \\
\hline CAN & 2.53 & 2.39 & 2.54 \\
\hline GBR & 2.19 & 2.06 & 2.12 \\
\hline IRE & 4.46 & 4.42 & 4.42 \\
\hline FRA & 2.54 & 2.64 & 2.51 \\
\hline SPA & 4.05 & 4.17 & 4.07 \\
\hline ITA & 2.41 & 2.56 & 2.41 \\
\hline POR & 2.60 & 2.59 & 2.56 \\
\hline $\mathrm{HOL}$ & 2.10 & 2.11 & 2.05 \\
\hline BEL & 3.19 & 2.94 & 3.16 \\
\hline DEN & 2.04 & 2.06 & 2.04 \\
\hline SWE & 2.39 & 2.43 & 2.36 \\
\hline NOR & 1.63 & 1.66 & 1.61 \\
\hline FIN & 3.26 & 3.23 & 3.27 \\
\hline AUT & 1.85 & 1.89 & 1.85 \\
\hline SWI & 1.36 & 1.31 & 1.35 \\
\hline \multicolumn{4}{|l|}{ Weighted Statistics } \\
\hline$\overline{\mathrm{R}^{2}}$ & 0.99 & 0.99 & 0.99 \\
\hline F-statistics & 3328.53 & 2919.22 & 2240.19 \\
\hline Durbin-Watson & 1.90 & 1.81 & 1.89 \\
\hline Number of Observations & 140 & 140 & 140 \\
\hline
\end{tabular}

a Estimation method : Generalized Least Square Dummy Variables (with cross-section weights); t-statistics are in parentheses. 


\section{IZA Discussion Papers}

No. Author(s)

81

T. J. Hatton

S. Wheatley Price

82

K. A. Konrad

83

R. Euwals

84

C. M. Schmidt

85

S. Pudney

M. A. Shields

86

J.P. Haisken-DeNew

C. M. Schmidt

87

T. K. Bauer

88

O. Bover

P. Velilla

89

S. Neuman

90

H. Lehmann

J. Wadsworth

91

M. Lechner

M. Lechner

94

M. Eichler

M. Lechner

95

P. Cahuc

A. Zylberberg

96

P. Cahuc

A. Zylberberg
Title

Area

Date

Migration, Migrants and Policy in the United

1

$12 / 99$

Kingdom

Privacy, time consistent optimal labor income

3

$12 / 99$

taxation and education policy

Female Labour Supply, Flexibility of Working Hours, 1 and Job Mobility in the Netherlands

The Heterogeneity and Cyclical Sensitivity of 1 Unemployment: An Exploration of German Labor Market Flows

Gender and Racial Discrimination in Pay and 5/6 Promotion for NHS Nurses

Money for Nothing and Your Chips for Free?

The Anatomy of the PC Wage Differential

Educational Mismatch and Wages in Germany

1

Migration in Spain: Historical Background and 1

Current Trends

Aliyah to Israel: Immigration under Conditions of 1 Adversity

Tenures that Shook the World: Worker Turnover in 4

Russia, Poland and Britain

Identification and Estimation of Causal Effects of 6

Multiple Treatments Under the Conditional

Independence Assumption

The Rate of Return to Private Schooling

5

An Evaluation of Public-Sector-Sponsored

6

Continuous Vocational Training Programs in East

Germany

An Evaluation of Public Employment Programmes 6

in the East German State of Sachsen-Anhalt

Job Protection, Minimum Wage and Unemployment 3

Redundancy Payments, Incomplete Labor

3

Contracts, Unemployment and Welfare
$12 / 99$

$12 / 99$

12/99

12/99

$12 / 99$

$12 / 99$

12/99

$12 / 99$

$12 / 99$

$12 / 99$

12/99

$12 / 99$

$12 / 99$

$12 / 99$ 
Matching Model with Uncertainty -

An Extension of Mortensen and Pissarides (1994)
G. Brunello
B. Parigi

Ownership or Performance: What Determines

Board of Directors' Turnover in Italy?

Modeling Financial Incentives to Get Unemployed Back to Work

109 G. J. van den Berg

Combining Micro and Macro Unemployment 
114 G. Brunello

A. Medio

115 A. Cigno

F. C. Rosati

116 C. Belzil

117 S. Bender
A. Haas
C. Klose

118 M. A. Shields M. E. Ward

119 A. Lindbeck

D. J. Snower

120 P. T. Pereira P. S. Martins

J. C. van Ours

D. Munich

J. Svejnar

K. Terrell

123 J. Hunt

124 R. T. Riphahn

125 F. Büchel

J. R. Frick

126 J. Fersterer

R. Winter-Ebmer

127

M. Karanassou

D. J. Snower

128 O. Ashenfelter

D. Ashmore

O. Deschênes

129 B. R. Chiswick M. E. Hurst

130 G. Brunello

S. Comi

C. Lucifora

B. R. Chiswick
An Explanation of International Differences in

Education and Workplace Training

Why do Indian Children Work, and is it Bad for Them?

Unemployment Insurance and Subsequent Job

Duration: Job Matching vs. Unobserved

Heterogeneity

IAB Employment Subsample 1975-1995.

Opportunities for Analysis Provided by the

Anonymised Subsample

Improving Nurse Retention in the British National

Health Service: The Impact of Job Satisfaction on Intentions to Quit

The Division of Labor and the Market for

Organizations

Does Education Reduce Wage Inequality?

Quantile Regressions Evidence from Fifteen

European Countries

Do Active Labor Market Policies Help Unemployed

Workers to Find and Keep Regular Jobs?

Returns to Human Capital under the Communist

Wage Grid and During the Transition to a Market

Economy

Why Do People Still Live in East Germany?

Rational Poverty or Poor Rationality? The Take-up of Social Assistance Benefits

The Income Portfolio of Immigrants in Germany -

Effects of Ethnic Origin and Assimilation. Or:

Who Gains from Income Re-Distribution?

Smoking, Discount Rates, and Returns to

Education

Characteristics of Unemployment Dynamics: The

Chain Reaction Approach

Do Unemployment Insurance Recipients Actively

Seek Work? Evidence From Randomized Trials in

Four U.S. States

The Employment, Unemployment and

Unemployment Compensation Benefits of

Immigrants

The Returns to Education in Italy: A New Look at the Evidence

5

$3 / 00$

Are Immigrants Favorably Self-Selected? An

Economic Analysis

2

$2 / 00$

3

$2 / 00$

3

$2 / 00$

5

$2 / 00$

$2 / 00$

$2 / 00$

$3 / 00$

$3 / 00$

$3 / 00$

$3 / 00$

$3 / 00$

$3 / 00$

$3 / 00$

$1 / 3 \quad 3 / 00$

$13 / 00$


Empirical Analysis within the Augmented Solow Model

Wages, Hours and Human Capital over the

The Effects of Public Sector Sponsored Training on Individual Employment Performance in East Germany

142 J. J. Dolado F. Felgueroso

J. F. Jimeno

Explaining Youth Labor Market Problems in Spain: 3

Wage Determination in Russia: An Econometric Investigation

144 G. Saint-Paul

Flexibility vs. Rigidity: Does Spain have the worst of both Worlds?

Decomposition Analysis for a Binary Choice Model

Does the Recent Success of Some OECD Countries in Lowering their Unemployment Rates Lie in the Clever Design of their Labour Market Reforms?

148 L. Goerke

Employment Effects of Labour Taxation in an Efficiency Wage Model with Alternative Budget Constraints and Time Horizons 
J.-St. Pischke

151 M. Ward

152 J. J. Dolado

F. Felgueroso

J. F. Jimeno

153 A. S. Kalwij

M. Gregory

154 M. Gerfin

M. Lechner

155

J. Hansen

156
A. Björklund
T. Eriksson
M. Jäntti
O. Raaum
E. Österbacka

159 P.- J. Jost

M. Kräkel

160

M. Lofstrom

161
V. Gimpelson
D. Treisman
G. Monusova

162 C. Dustmann

M. E. Rochina-

Barrachina

163

R. A. Hart

Y. Ma

164 M. A. Shields

S. Wheatley Price

Z. MacDonald

M. A. Shields
Gender, Salary and Promotion in the Academic 5 Profession

The Role of the Minimum Wage in the Welfare 3

State: An Appraisal

Overtime Hours in Great Britain over the Period 3

1975-1999: A Panel Data Analysis

Microeconometric Evaluation of the Active Labour 6 Market Policy in Switzerland

The Duration of Immigrants' Unemployment Spells: $\quad 1 / 3$

Evidence from Sweden

Language Proficiency and Labour Market Per- 1

formance of Immigrants in the UK

Household Production, Full Consumption and $\quad 7$ the Costs of Children

Brother Correlations in Earnings in Denmark, 5 Finland, Norway and Sweden Compared to the United States

Preemptive Behavior in Sequential Tournaments

A Comparison of the Human Capital and Signaling Models: The Case of the Self-Employed and the Increase in the Schooling Premium in the 1980's

Public Employment and Redistributive Politics:

4

$6 / 00$

Evidence from Russia's Regions

Selection Correction in Panel Data Models: An 6 Application to Labour Supply and Wages

Why do Firms Pay an Overtime Premium?

5

$6 / 00$

Racial Harassment, Job Satisfaction and Intentions

5

$6 / 00$ to Quit: Evidence from the British Nursing Profession

Immigration in a High Unemployment Economy: 1 The Recent Danish Experience

The Impact of Alcohol Consumption on Occupa- 5 tional Attainment in England 

New Zealand and Australia

K. F. Zimmermann

Immigration Policy in Integrated National Economies $\quad 1$

Self-Employment and Earnings among High-Skilled 1 Immigrants in the United States

Industrial Relations and the Wage Differentials between Skilled and Unskilled Blue-Collar Workers within Establishments: An Empirical Analysis with Data of Manufacturing Firms

177 B. R. Chiswick

Immigrant Adjustment in Israel: Literacy and 1 